\title{
The Effects of Media Slant on Firm Behavior
}

\section{Citation}

Baloria, Vishal P., and Jonas Heese. "The Effects of Media Slant on Firm Behavior." Journal of Financial Economics 129, no. 1 (July 2018): 184-202.

\section{Published Version}

https://doi.org/10.1016/j.jfineco.2018.04.004

\section{Permanent link}

http://nrs.harvard.edu/urn-3:HUL.InstRepos:41845079

\section{Terms of Use}

This article was downloaded from Harvard University's DASH repository, and is made available under the terms and conditions applicable to Open Access Policy Articles, as set forth at http:// nrs.harvard.edu/urn-3:HUL.InstRepos:dash.current.terms-of-use\#OAP

\section{Share Your Story}

The Harvard community has made this article openly available.

Please share how this access benefits you. Submit a story.

\section{Accessibility}




$$
\text { H A R VAR D B US INESS S C HOOL }
$$

\section{The Effects of Media Slant on Firm Behavior}

Vishal P. Baloria Jonas Heese

Working Paper 18-015 


\title{
The Effects of Media Slant on Firm Behavior
}

\author{
Vishal P. Baloria \\ Boston College \\ Jonas Heese \\ Harvard Business School
}

Working Paper 18-015 not be reproduced without permission of the copyright holder. Copies of working papers are available from the author. 


\title{
The Effects of Media Slant on Firm Behavior
}

\author{
Vishal P. Baloria \\ Boston College \\ vishal.baloria@bc.edu \\ Jonas Heese* \\ Harvard University \\ jheese@hbs.edu
}

August 2017

\begin{abstract}
The media can impose reputational costs on firms because of its important role as an information intermediary and its ability to negatively slant coverage. We exploit a quasi-natural experiment that holds constant the information event across firms, but varies the availability of a major news outlet in local markets. We find that firms subject to the threat of slanted coverage suppress the release of negative information before the event and release it subsequently. Our results are consistent with theory on the active role firms can play in managing their reputational capital through anticipatory actions to avoid negative media coverage.
\end{abstract}

Keywords: media slant, reputational capital, strategic corporate decisions

JEL classification: D72, G30, G34

Data availability: All data are available from public sources identified in the paper.

We thank Bill Schwert (Editor) and an anonymous referee for insightful comments that have significantly improved this paper. We also appreciate helpful suggestions from Abigail Allen (discussant), Beth Blankespoor, Nerissa Brown, Mary Ellen Carter, Jeff Cohen, Jenelle Conaway, Emmanuel De George, David Godsell, Rani Hoitash, Amy Hutton, Thomas Keusch, Christian Laschewski (discussant), Krish Menon, Shail Pandit (discussant), Karthik Ramanna, Shiva Rajgopal, Sugata Roychowdhury, Ewa Sletten, Eugene Soltes, Ahmed Tahoun, Irem Tuna, Steve Utke, Florin Vasvari, and participants at the Boston Accounting Research Colloquium at Boston University, London Business School, the 2016 Accounting Conference at Temple University, the $10^{\text {th }}$ Annual Accounting Research Conference at Indian School of Business, the Conference on Capital Market-Based Accounting Research at University of Munster, and the 2017 American Accounting Association Annual Meeting for helpful comments. We also thank Botir Kobilov, Tristan Norcutt, Xiaonan Qin, and Rohit Singla for excellent research assistance. We are grateful to Joshua Clinton and Ted Enamorado for providing data on Fox News Channel availability.

* Corresponding author: jheese@hbs.edu. Harvard University, Soldiers Field Road, Boston, MA 02163, USA. Phone: 617-495-2827. Fax: 617-496-7387. 


\section{Introduction}

The media plays an important role in financial markets by processing and disseminating information about firms. As such, firms are sensitive to the way in which the media report and comment upon their decisions. This sensitivity arises because the media can influence the reputational capital of firms in the eyes of shareholders but also society at large (Dyck and Zingales, 2002). The potential for the media to generate public scrutiny disciplines firms' actions as the reputations of internal (e.g., managers and directors) and external (e.g., customers, or strategic and political allies) stakeholders is closely tied to the decisions of the firms. Ultimately, the extent to which a media source can influence the reputational capital of a firm depends on its reach (i.e., the size and nature of its audience) and its ability to slant certain decisions in a costly manner (i.e., negative characterization of firms’actions) (Dyck, Volchkova, and Zingales, 2008).

In spite of the media's potentially significant role in shaping corporate policy, there is limited empirical evidence on whether firms’ decisions are influenced by concerns over mediaimposed reputational costs. There are several reasons for the paucity of evidence. First, many media outlets themselves are concerned about their own reputation as a neutral source of information and are hesitant to slant information. Therefore, to show a media effect, one needs to focus on an outlet that has shown a willingness to slant coverage in a manner that can be costly

to firms. Second, information acquisition is a costly activity and not all stakeholders are willing to bear the costs of information acquisition. Thus, the outlet's reach in terms of the size of its audience and the type of news covered needs to be broad enough to inform firms' stakeholders, and ultimately influence firms’ actions. Third, media coverage is not a random choice but rather the product of profit maximization and other utility maximizing objectives (Mullainathan and 
Shleifer, 2005). Significant identification problems arise, because the same unobservable factors that influence media coverage can also influence firms’ actions.

We attempt to overcome these challenges by exploiting a quasi-natural experiment. Specifically, we exploit the gradual geographical expansion of Fox News Channel (FNC), a media outlet with a well-understood ability to slant news, in the late 1990's. FNC was introduced in October 1996 and its owner Rupert Murdoch promised news coverage slanted to the right of existing news sources. ${ }^{1}$ In the years that followed, FNC spread quickly across the U.S., although cable companies in neighboring towns gained access in different years, creating idiosyncratic differences in access to the outlet.

This experiment helps to address the three challenges outlined above. First, FNC had clearly stated ideological preferences (i.e., right of all other major news outlets as per Groseclose and Milyo (2005)), indicating its willingness to slant news coverage in a negative and thus costly way - at least for some firms. Second, it was available to a large segment of the U.S. population (17\% by June 2000) and the political nature of its news coverage (as well as its overlap with business news) ensured that it was watched by the types of stakeholders that firms would be concerned about. Thus, its reach was arguably broad enough to influence the actions of firms. ${ }^{2}$ Prior research has also validated that the gradual introduction of FNC across the U.S. was unrelated to the political ideology of voters or incumbents in particular congressional districts but was primarily driven by the ease with which Fox was able to negotiate an agreement with local cable companies (DellaVinga and Kaplan, 2007; Hopkins and Ladd, 2013; Clinton and

\footnotetext{
${ }^{1}$ The major television news networks at that time included broadcast (ABC, CBS, and NBC) and cable (CNN) networks. These four outlets were available to almost all U.S. households. MSNBC also launched in 1996 but had minimal viewership until 2008 when it adopted a distinctively liberal perspective (Groseclose and Milyo, 2005).

${ }^{2}$ Anecdotal evidence suggests that corporate managers actively consume television news coverage on issues of interest to their particular firms (Auletta, 2001).
} 
Enamorado, 2014). Therefore, it is unlikely that our treatment variable (FNC availability in firms’ local markets) could be affected by firm decisions, mitigating endogeneity concerns.

We conduct a detailed review of transcripts for a cross-section of the most popular FNC shows (the "Cavuto Business Report", "Fox News Sunday", "Special Report with Brit Hume", and "The O'Reilly Factor"), and compile a list of all firms discussed or interviewed on these shows during the year 2000. We find that a disproportionate number of firms covered by FNC are located in areas with FNC availability. We use evidence of this local bias to establish that firms headquartered in areas with FNC access had particularly strong incentives to monitor developments in their local information environment and alter their behavior accordingly. These incentives arise because the threat of slanted coverage is higher for these firms.

Given the nature of our experiment, we focus on firms with ties to the Democratic Party. Our maintained assumption is that these left-leaning firms are particularly subject to the threat of slanted coverage by a right-leaning media outlet. ${ }^{3}$ We take a cross-sectional approach, whereby a fraction of the Democratic firms are located in local markets with FNC access whereas others are not. We use non-political firms as our benchmark as they are less likely to be affected by FNC's slanted coverage. We also introduce an intertemporal component to our tests by anchoring our analysis around the 2000 election. Like firms, politicians are also concerned about their reputation (Dyck, Volchkova, and Zingales, 2008), especially before elections, and look to allied firms to take actions to help preserve their reputational capital. We focus on firms' actions that prior research has shown to be of importance to firms and politicians in managing their reputations: information disclosure (Piotroski, Wong, and Zhang, 2015; Baloria and Klassen,

\footnotetext{
${ }^{3}$ Faccio, Masulis, and McConnell (2006) note that media outlets cover politically connected firms more actively. We confirm this general finding in our specific context through our review of transcripts of FNC shows. Using chisquare tests, we observe higher levels of Democratic firms being discussed or interviewed on FNC than expected.
} 
2017) as well as employment reduction and plant closure decisions (Bertrand, Kramarz, Schoar, and Thesmar, 2007; Ramanna and Roychowdhury, 2010).

We use a triple differences research design. We exploit two sources of cross-sectional variation (i.e., FNC availability vs. no FNC availability and Democratic vs. non-political firms) and one source of intertemporal (i.e., pre-versus-post-election) variation. The cross-sectional variation controls for time-varying effects that coincide with our sample period while the intertemporal variation controls for time-invariant firm-and-district-specific characteristics. We supplement our triple differences research design with additional tests to mitigate the possibility that firm characteristics or concurrent events can explain our results.

We identify firms with ties to the Democratic Party using firms' soft money contributions, which are well-suited to identify Democratic firms for our purpose. Unlike political action committee (PAC) contributions, firms tend to concentrate their soft money contributions more towards one party rather than (equally) distributing funds to both parties. Soft money donations are also larger in magnitude as there are no donation limits, and are donated to the party rather than candidate (Apollonio and Raja, 2004; Jayachandran, 2006). Prior research has validated that soft money contributions are correlated with substantial economic benefits for firms (Jayachandran, 2006; Knight, 2006), helping us to establish that Democratic-leaning firms have economic incentives to internalize the preferences of the Democratic Party. Our Democratic sample comprises of 186 firms over the 1998-2003 period. ${ }^{4}$ Our non-political sample comprises of 4,226 other firms over the same period. Democratic firms headquartered in congressional districts with FNC availability form our treatment sample. As in Clinton and Enamorado (2014),

\footnotetext{
${ }^{4}$ In the lead up to the election, FNC reported and criticized corporate campaign contributions to the Democratic Party extensively. In particular, we counted 227 mentions of corporate campaign contributions in our detailed review of transcripts for a cross-section of the most popular FNC shows during 2000. Thus, connections arising from soft money contributions had the potential to subject Democratic-leaning firms to significant reputational costs.
} 
we use data collected from the Television and Cable FactBook on the number of subscribers per Cable Company in each congressional district with access to FNC. The data set encompasses FNC availability in 14,748 towns in 35 states for the years 1998, 2000, and 2003.

Our primary analysis focuses on a summary measure of information disclosure as reflected in stock-price behavior. We employ a stock-price crash risk methodology to capture the suppression and subsequent release of negative financial information in the pre- and postelection year (Chen, Hong, and Stein, 2001; Jin and Myers, 2006). This measure has been used and extensively validated in an event-study setting by Piotroski, Wong, and Zhang (2015). Firms with greater negative return skewness are more likely to have large negative stock-price movements, which we interpret as indicative of the release of negative financial information. We find that treatment firms release less (more) negative financial information in the pre-election (post-election) year. This intertemporal pattern is consistent with the initial suppression and subsequent release of bad news in response to heightened costs of bad news revelation.

Our theoretical framework maintains that firms are more likely to be responsive to potential reputational costs when their reputation is central to maintaining profitability. Such firms include those that have significant external contractual relationships (e.g., large firms), including those with the government (Dyck and Zingales, 2002; Dyck, Volchkova, and Zingales, 2008). Thus, we expect our results to be concentrated among larger firms (henceforth "more visible firms"). Our detailed review of FNC transcripts helps to reinforce our cross-sectional predictions. In particular, we find that a disproportionate number of firms discussed or interviewed on FNC are more visible firms. Consistent with expectations, we show that the suppress-and-release pattern is concentrated in more visible firms. 
One advantage of our measure of information disclosure is that we are able to capture the flow of all value-relevant information incorporated in stock prices. However, this aggregate approach comes at the expense of granularity in that it does not allow us to identify specific actions taken by firms. To help triangulate evidence, we also conduct supplementary analyses where we examine specific actions treatment firms potentially use to suppress negative information. Following Dyck and Zingales (2002), we argue that the media plays a significant role in shaping the public image of a firm and thereby encourages firms to take socially acceptable actions. These actions can be, but are not necessarily, value-destroying. ${ }^{5}$ We focus on real actions that are likely to be negatively covered by the media: major employment and investment reductions. Prior research shows that because current employment and investment levels significantly influence voters, politically connected firms cater to the needs of their politicians by avoiding layoffs and plant closures prior to an election (Bertrand, Kramarz, Schoar, and Thesmar, 2007). We find that treatment firms issue fewer layoff and plant closure announcements in the pre-election year (relative to other years and control firms). As announcements of layoffs and plant closures are typically bundled together, we also examine annual financial statement data on employment as well as property, plant, and equipment levels to shed further light on each of the two actions. Consistent with our announcement analyses, we find that treatment firms are less likely to have large workforce and investment reductions in the pre-election year. We also find that treatment firms are more likely to have large investment reductions in the post-election year, consistent with the suppress-and-release pattern we show

\footnotetext{
${ }^{5}$ In the Dyck and Zingales (2002) framework, actions that are socially acceptable can be value-destroying or valueenhancing depending on the context. Similarly, reductions in employment and investment can be value-destroying or value-enhancing. For our sample firms, the average stock-price reaction is significantly negative for layoff and plant closure announcements. However, a negative reaction is not necessary for our predictions to hold, as we only require that the announcements are viewed negatively by the public at large (not only by investors).
} 
with our stock return skewness tests. Collectively, this evidence suggests that the prospect of negatively slanted media coverage encourages treatment firms to delay real actions.

We conduct additional tests to corroborate our main findings. First, we supplement our use of industry-by-year and state fixed effects with other fixed effects structures. Second, we conduct a falsification test to demonstrate that our results are not driven by time-invariant unobservable characteristics of firms or geographical areas. Third, we rule out the possibility that FNC access mainly captures information availability to an additional media source rather than media slant by controlling for one measure of information availability. Fourth, we control for a commonly used measure of policy uncertainty to rule out the possibility that our results can be explained by election-related uncertainty altering firm behavior. Finally, we run alternative specifications based on subsamples of firms with particularly strong incentives to internalize the preferences of political parties. Across all of these tests, we find consistent results.

Our research is related to the growing body of economics research on media slant. Theoretical models examine forces that give rise to this pervasive and salient characteristic of the media (Mullainathan and Shleifer, 2005; Baron, 2006; Besley and Prat, 2006; Gentzkow and Shapiro, 2010). Research in economics and political science finds that media slant influences actions of voters (DellaVigna and Kaplan, 2007; Gerber, Karlan, and Bergan, 2009; Hopkins and Ladd, 2013) and politicians (Clinton and Enamorado, 2014). We advance this research by demonstrating that media slant can influence actions of agents in financial markets.

Our study also contributes to research on the effects of media coverage on firm and managerial actions. Extant research demonstrates that the media can play a corporate governance role by exposing wrongdoing and thereby encouraging firms to take remedial actions (Dyck, Volchkova, and Zingales, 2008). There is evidence to support the media's governance role in 
bringing corporate fraud to light (Miller, 2006; Dyck, Morse, and Zingales, 2010), improving the quality of corporate boards (Joe, Louis, and Robinson, 2009), encouraging managers to abandon value-destroying acquisitions (Liu and McConnell, 2013) and behave in socially acceptable ways (Dyck and Zingales, 2002), as well as curbing excess executive compensation (Core, Guay, and Larcker, 2008; Kuhnen and Niessen, 2012) and insider trading (Dai, Parwada, and Zhang, 2015; Rogers, Skinner, and Zechman, 2016). While these studies acknowledge that corporate decisions are influenced by potential and actual costs that media could impose, evidence that managers can anticipate media coverage of corporate activities and alter their behavior ex ante to avoid negative coverage is absent. Our contribution to this literature is to provide evidence of firms' strategic behavior in response to anticipated slanted media coverage.

Finally, from a research design perspective, our study achieves stronger identification than media studies that employ only cross-sectional designs. In the spirit of some recent studies in this literature (Engelberg and Parsons, 2011; Dougal, Engelberg, Garcia, and Parsons, 2012; Peress, 2014), our research design allows us to more confidently overcome alternative explanations and endogeneity bias arising from correlated omitted variables or reverse causality. We use the unique circumstances surrounding the diffusion of FNC and its overlap with the 2000 election to identify the effect of media slant on firm behavior. However, the uniqueness of the situation also makes it difficult to generalize the effect, particularly to the current ideologically segmented media environment. While there is some evidence of slant in other forms of media, it is important not to over generalize our findings to all types of media or all time periods.

The remainder of this paper is organized as follows. Section 2 reviews prior literature, provides institutional background on the setting, and presents our hypothesis. Section 3 describes our sample and research design. Section 4 discusses our results, and Section 5 concludes. 


\section{Literature review, background, and hypothesis}

\subsection{The role of the media in financial markets}

Understanding the incentives of the media in its coverage of corporations is a developing area of research. As described in Miller and Skinner (2015), the extant research has largely focused on two questions: (1) does the media play a corporate governance role in financial markets? (2) does the media play an information role and affect stock-price formation through provision of value-relevant information? As described earlier, there is evidence to support the media's governance role in financial markets. There is also evidence to support the information role as media coverage affects stock-price formation by reducing informational frictions (Fang and Peress, 2009; Bushee, Core, Guay, and Hamm, 2010; Peress, 2014), cash flow mispricing (Drake, Guest, and Twedt, 2014), and thereby stimulating trading activity around earnings announcements (Engelberg and Parsons, 2011).

At the same time, prior research has argued that the media also caters to consumers (Jensen, 1979). Evidence of media biases relating to consumers' political preferences provide support for this view (Mullainathan and Shleifer, 2005; Gentzkow and Shapiro, 2010). The media has also been shown to face conflicts of interests in its coverage of firms with which it has advertising relationships ( Reuter and Zitzewitz, 2005; Gurun and Butler, 2012).

Collectively, this body of research suggests that the media faces a number of incentives that can shape the manner in which it accumulates and reports news about firms.

\subsection{Reputational capital and the media}

Dyck and Zingales (2002) and Dyck, Volchkova, and Zingales (2008) focus on the corporate governance role of the media and describe different ways in which the media can influence reputational capital of firms (and by extension their internal and external shareholders). 
In their framework, the media can influence the reputation of firms in the eyes of society at large, thereby incentivizing firms to avoid actions that can deplete reputational capital.

The extent to which a media outlet can influence the reputational capital of a firm depends on its reach and its ability to slant certain decisions in a costly manner. The outlet's reach is important because the media disseminates news of firms' actions and by doing so increases the probability that an action is known to a particular audience and carries a reputational cost. The ability to slant is important because the media characterizes firms' actions and thereby helps to shape perceptions of those actions among the public.

\subsection{Background on the setting}

Examining the influence of media slant on firm behavior is challenging because the decision to slant news is not random, but rather the product of profit maximization and other utility maximizing objectives. An identification problem arises because the same unobservable factors that influence the presence of media slant can influence behavior of economic agents such as managers and their firms. As described earlier, we maintain that the entry of Fox News Channel in local cable markets provides us with an experiment to overcome this problem. Groseclose and Milyo (2005) compute an index of political orientation of news programs and show that FNC is significantly to the right of all other major media outlets, indicating its willingness to slant news and altering the political information available to voters. In fact, studies

show that FNC availability decreased the vote share for the Democratic Party in the 2000 election (DellaVigna and Kaplan, 2007; Hopkins and Ladd, 2014).

At the time of the launch, Rupert Murdoch's stated goal was to make FNC available to as many people as possible to compete with CNN (DellaVigna and Kaplan, 2007). The availability of FNC by 2000 in a particular town is primarily based on the ease with which Fox was able to 
negotiate an agreement with local cable companies, creating idiosyncratic variation in the diffusion of FNC. Clinton and Enamorado (2014) find that the availability of FNC in a particular district is not related to political characteristics of the districts' House representatives or voters. Hopkins and Ladd (2014) conclude that FNC's expansion “was not politically driven,” but FNC availability tended to be concentrated in larger U.S. towns with more cable channels. Within our sample firms, the average population in districts with and without FNC access is very similar (i.e., 625,402 and 641,687, respectively), suggesting that the district population is unlikely to influence our inferences. In the years that followed its 1996 launch, FNC spread quickly, and by the year 2000, FNC was available in 22 of the 35 states and accessible to $17 \%$ of the U.S. population. Figure 1 shows a map of FNC availability in 2000 across the U.S.

- Please insert Figure 1 about here -

The setting also allows us to identify firms that are especially sensitive to reputational concerns - firms with ties to the Democratic Party. Our maintained assumption is that these leftleaning firms are particularly subject to the threat of slanted coverage by a right-leaning media outlet. In untabulated analysis, we find that a disproportionate number of firms covered by FNC are Democratic-leaning firms, helping to support our assumption. Important for our study, the spread of FNC coincides with the 2000 election, increasing the likelihood that firms are willing to take actions to avoid public scrutiny. Like firms, politicians are also concerned about their reputation (Dyck, Volchkova, and Zingales, 2008), especially before elections, and look to allied firms to take actions to help preserve their reputational capital (Bertrand, Kramarz, Schoar, and Thesmar, 2007). ${ }^{6}$

\footnotetext{
${ }^{6}$ Anecdotal evidence suggests that corporate executives believe that the economic prospects of their firms are closely tied to their soft money contributions. For example, Alan Hassenfeld, CEO of Hasbro Inc. from 1989-2008, noted that, "Many in the corporate world view large soft money donations as a cost of doing business. ... I remain convinced that in some of the more publicized cases, federal officeholders actually appear to have sold themselves
} 


\subsection{Limitations of the setting}

We acknowledge that FNC is not the only source of information and other media outlets could also provide negative coverage. However, because FNC explicitly stated its ideological position, delivered it by the most readily consumed news outlet at the time (i.e., television), and influenced voters and politicians, it was likely to be of particular interest to managers.

FNC focuses on national, rather than local, issues and thus could still cover the behavior of firms located in districts in which it is not available. This would confound our ability to detect differences as all Democratic firms would have incentives to suppress negative financial information, regardless of FNC availability. ${ }^{7}$ However, we expect the effect to be strongest for Democratic firms located in areas with FNC availability. Prior research finds that local stakeholders have a greater ability to influence firm behavior and, as a result, firms pay particularly close attention to developments in their local information environment (Ayers, Ramalingegowda, and Yeung 2011; Chhaochharia, Kumar, and Niessen-Ruenzi, 2012; Hutton, Jiang, and Kumar, 2015). These studies maintain that because local stakeholders encounter lower costs in communicating with managers, firms are particularly responsive to the needs of stakeholders in their local environment.

In support of this assumption, we conduct a detailed review of transcripts for a crosssection of the most popular FNC shows (the "Cavuto Business Report", "Fox News Sunday", "Special Report with Brit Hume”, and “The O'Reilly Factor"), and compile a list of all firms discussed or interviewed on these shows in the year 2000. We report descriptive information

and the party cheaply. They could have gotten even more money, because of the potential importance of their decisions to the affected business."

${ }^{7}$ Across all of our tests outlined in Section 4, we find no evidence that Democratic firms without FNC availability suppress and subsequently release negative financial information. 
relating to this detailed review in Table $1 .{ }^{8}$ Over this time period, we find that 164 publicly traded firms are discussed or interviewed on FNC. 90 of these firms are located in the 35 states for which we have FNC-availability data; the other 74 firms are located in states for which we do not have FNC-availability data. In Panel A of Table 1, the chi-square statistic tests the null hypothesis that there is no relation between a firm being headquartered in an area with FNC availability and being discussed or interviewed on FNC in the year 2000. The observed number of firms headquartered in an area with FNC availability and discussed or interviewed on FNC is 53 (59\%), significantly higher than the expected number of firms, 43 (47\%), at the 5\% level of statistical significance. ${ }^{9}$ This suggests that a disproportionate number of firms discussed or interviewed on FNC are located in areas with FNC availability. We label this "local bias". ${ }^{10}$

- Please insert Table 1 about here -

In addition to the descriptive evidence provided above, we also look to the literature to provide guidance on why FNC could have exhibited a local bias. Gurun and Butler (2012) argue that media sources exhibit a local bias because audiences care about local firms (i.e., as they are more likely to work for or be familiar with these firms).

In sum, we believe evidence of FNC's local bias in combination with a discussion of the catering incentives that could have given rise to this bias helps to support our expectations.

\subsection{Hypothesis}

\footnotetext{
${ }^{8}$ Table 1 includes 4,123 unique firms as of 2000 as opposed to our main sample, which includes 4,412 unique firms between 1998 and 2003, accounting for the differences in sample size between Table 1 and Table 2.

${ }^{9}$ The chi-square test statistic measures the divergence of the observed data from the values that would be expected under the null hypothesis of no association, where the expected values for each cell in the two-way tables is equal to (row total*column total)/number of total observations. As such, the expected values explicitly incorporate the distribution of the row (i.e., proportion of firms that were and were not discussed on FNC shows) and column (i.e., proportion of firms that were and were not located in areas with FNC access).

${ }^{10}$ In our setting, local bias refers to the tendency of a national news outlet to disproportionately cover firms in areas in which it is available. This definition differs from the more traditional usage of the term "local bias" in other settings (Gurun and Butler, 2012), where it refers to the tendency of a local news outlet (e.g., Boston Globe) to disproportionately cover firms in areas in which it is available (e.g., within 100 miles of Boston).
} 
We propose that—because of the media outlet's slanted coverage — the availability of the outlet in particular districts creates incentives for treatment firms located in these districts to suppress negative information during the election, and subsequently release such information after the election. This incentive arises because we expect that the revelation of negative information by treatment firms would be publicized in a slanted manner by the media outlet, and adversely affect the reputational capital of treatment firms and allied politicians. We expect the suppressed negative financial information to be released in the period following the election when the costs of bad news revelation are lower. Our hypothesis can be summarized as follows:

Hypothesis: Treatment firms located in districts with slanted media coverage availability temporarily suppress negative information before the election and subsequently release it following the election.

We note that our hypothesis is not without tension. First, treatment firms may not perceive the media outlet, a new and relatively unproven entrant in the media market, as a credible threat to their reputational capital. Second, even if treatment firms perceive the media outlet as a credible threat, these firms may not be concerned about the imposition of reputational costs as attributing the behavior of an individual firm to a political party is a difficult task for any media outlet. ${ }^{11}$ Finally, deferral of negative financial information can be costly, thereby requiring that the benefits associated with such behavior are sufficiently high to offset the costs.

\section{Sample, research design, and descriptive statistics}

\subsection{Sample}

We obtain data on Fox News Channel availability and the number of subscribers per congressional district from Clinton and Enamorado (2014), who built upon the data collected by

\footnotetext{
${ }^{11}$ Fox did not formally enter into business news until the launch of Fox Business Network (FBN) in 2007. Prior to FBN, business news was discussed to the extent that it related to broader societal issues or in specific shows (i.e., Cavuto Business Report).
} 
DellaVigna and Kaplan (2007). DellaVigna and Kaplan (2007) use the Television \& Cable Factbook to collect the number of FNC subscribers for 9,256 towns in 28 states, but could not identify the congressional district for an additional 5,462 towns. Clinton and Enamorado (2014) use the Congressional District Atlas for the 103rd Congress to identify the congressional district (or districts) for these additional towns which extends the data to districts in Florida, Delaware, Indiana, Illinois, Oklahoma, Oregon, and Maryland, leading to a final data set of FNC availability and subscribers in 14,748 towns in 35 states for the years 1998, 2000, and 2003. Thus, we restrict our sample to firms headquartered in one of the 35 states with FNC data. ${ }^{12}$

Our sample is concentrated around the 2000 election and covers the years 1998-2003. We begin with 1998 because this is the first year for which data on Fox News Channel subscriptions is available. The sample ends in 2003 to ensure that our sample period does not extend into the 2004 election. We exclude foreign firms cross-listed in the U.S. because foreign firms are legally not allowed to influence electoral outcomes in the United States and thus cannot make soft money contributions or create PACs (Milyo, Primo, and Groseclose, 2000).

After applying data filters, we have 16,960 firm-year observations, representing 4,412 distinct firms as shown in Table 2. Our Democratic-leaning sample is comprised of 670 firmyear observations of firms contributing soft money to the Democratic Party, representing 186 distinct firms. ${ }^{13}$ The remaining observations constitute our non-political firms.

- Please insert Table 2 about here -

\footnotetext{
${ }^{12}$ We do not have FNC data for the following states: Arizona, Colorado, Georgia, Kansas, Kentucky, Louisiana, Mississippi, Montana, North Carolina, Nebraska, New Mexico, Nevada, Texas, Washington, and West Virginia.

${ }_{13}^{13}$ Jayachandran (2006) conducts an event study surrounding Senator Jeffords' May 2001 decision to switch parties. This decision caused a shift in Senate power (from Republican to Democratic control) that allows the author to measure the effect of a political shift on the market value of firms tied (through soft money contributions) to each of the parties. The results suggest that each dollar in soft money donated to the Democratic or Republican Party during the 1999-2000 election cycle is associated with a $\$ 2,300$ increase or decrease in a firm's market value in response to the event (see Table 2 on pp. 408-409 of her paper). This study helps to demonstrate that soft money contributors' future economic prospects are closely tied to the success of the political party with which they are aligned.
} 


\subsection{Research design}

We use the following regression model to examine the relation between the availability of a slanted media outlet and suppression of negative financial information around the 2000 election (where the subscript $i$ represents the firm and $t$ the year):

$$
\begin{aligned}
& \text { Ncskew }_{i, t}=\alpha+\beta_{1} \text { FNC }_{i, t}+\beta_{2} \text { Dem_Firm }_{i, t}+\beta_{3} \text { Election }_{i, t}+\beta_{4} \text { Post_Election }_{i, t} \\
& +\beta_{5} F_{N C_{i, t}} * \text { Dem_Firm }_{i, t}+\beta_{6} F_{N} C_{i, t} \text { X Election }{ }_{i, t}+\beta_{7} \text { FNC }_{i, t} x \text { Post_Election }_{i, t} \\
& +\beta 8 \text { Dem_Firm }_{i, t} x \text { Election }_{i, t}+\beta 9 \text { Dem_Firm }_{i, t} x \text { Post_Election } i, t \\
& +\beta_{10} \text {FNCC }_{i, t} * \text { Dem_Firm }_{i, t} x \text { Election }_{i, t}+\beta_{11} \text { FNC }_{i, t} * \text { Dem_Firm }_{i, t} X \\
& \text { Post_Election }_{i, t}+\Sigma_{n} \beta_{n} \text { Controls }_{i, t}+\varepsilon_{i, t}
\end{aligned}
$$

Ncskew is our measure of firm-level variation in the flow of negative information into stock prices. We use the crash-risk methodology developed by Chen, Hong, and Stein (2001) and Jin and Myers (2006). We follow Piotroski, Wong, and Zhang (2015) and employ this methodology in an event period setting. Specifically, we use the negative skewness statistic which captures the presence of large, negative stock-price movements. Firms with greater negative skewness are more likely to have large negative stock-price movements, which we interpret as indicative of the release of material negative financial information. Ncskew ${ }_{\mathrm{i}, \mathrm{t}}$ is measured as the third moment of each stock's weekly residual returns, divided by the cubed standard deviation of weekly residual returns, times negative one, in year $t$. For each firm-year, we assign weekly returns to the 12-month period ending three months after the firm’s fiscal yearend. We use one-year intervals because the skewness statistic is required to be measured over longer periods. ${ }^{14}$ By multiplying the statistic by negative one, we can interpret an increase in Ncskew $w_{\mathrm{i}, \mathrm{t}}$ as reflecting an increase in the release of negative financial information. Similarly, we interpret a decrease in $N c s k e w_{i, t}$ as reflecting the suppression of negative financial information.

\footnotetext{
${ }^{14}$ Piotroski, Wong, and Zhang (2015) examine this issue thoroughly by supplementing their annual specifications with quarterly specifications and find stronger results in their annual specifications. In addition, our subsequent tests also rely on Compustat data on the number of employees, which is only available on an annual basis.
} 
$N_{c s k e} w_{i, t}$ is calculated using the residuals from annual, firm-specific estimations of the following market model using firm i's weekly returns in year $t$ :

$$
r_{i, t}=\alpha_{0}+\beta_{1} r_{m, t-2}+\beta_{2} r_{m, t-1}+\beta_{3} r_{m, t}+\beta_{4} r_{m, t+1}+\beta_{5} r_{m, t+2}+\varepsilon_{i, t}
$$

where $r_{i, t}$ is the return of firm $i$ in week $t$ and $r_{m, t}$ is the return on the Center for Research on Security Prices (CRSP) value-weighted market index in week $t$. We include the lead and lag terms for the market return to allow for trading frictions and nonsynchronous trading.

FNC is either the logged number of subscribers with FNC access in the congressional district in which firm $i$ is headquartered in year $t$ or an indicator equal to one if firm $i$ is headquartered in a district with FNC availability, and zero otherwise. While the first FNC measure captures the extent of FNC access, the latter captures the existence of FNC access. Relative to the continuous variable, which captures the number of FNC subscriptions within each congressional district, the indicator variable allows for less variation, and thus represents a less powerful measure of the construct of interest.

Dem_Firm is an indicator equal to one if firm $i$ is a soft money contributor to the Democratic Party as reported by Center for Responsive Politics (CRP), and zero otherwise.

Election is equal to one for all firms with fiscal year ends between July 31, 1999 and June 30, 2000, i.e., the firm-year before the political event, and zero otherwise. This time window ensures that firms' financial statements are likely to be released before Election Day, i.e., November 7, 2000. Post_Election is equal to one for all firms with fiscal year ends between July 31, 2001 and June 30, 2002, i.e., the firm-year after the political event window, and zero otherwise. We define fiscal year 2001 (rather than fiscal year 2000) as the Post_Election variable because Piotroski, Wong, and Zhang (2015) find that the suppression of negative financial information by firms persists for up to three months after the end of a political event. They argue 
because key policy decisions are typically made during this time period, the potential for scrutiny persists for several months after the end of the political event. As the outcome of the 2000 presidential election was not known until December 13, 2000 because of the Florida recount, this effect is of particular importance in our setting. Figure 2 summarizes our empirical design.

- Please insert Figure 2 about here -

The three-way interactions between FNC, Dem_Firm, and Election and Post_Election capture the incremental effect of FNC on the incentives of Democratic-leaning firms to suppress (release) negative financial information during the period prior to (subsequent to) the 2000 election. A decline in negative skewness during our event window, i.e., a negative and significant coefficient $\beta_{10}$, is interpreted as a temporary reduction in the flow of negative information about these firms. A subsequent increase in negative skewness in the period following the event window, i.e., a positive and significant coefficient $\beta_{11}$, is interpreted as the release of the previously suppressed negative financial information.

We also include a number of firm characteristics to control for other determinants of negative skewness. Piotroski, Wong, and Zhang (2015) find a negative association between firm size and negative skewness, which they interpret as consistent with larger firms being less likely to experience dramatic price declines due to their diversified operations and richer information environment. Thus, we control for firm size (Log_Mark_Cap), measured as the natural logarithm of a firm's market value of equity at the end of year $t$. Growth results in greater susceptibility to price crashes, and therefore we control for firm growth (Chg_Sales), measured as the sales growth in year $t$. As the systematic and idiosyncratic risk characteristics of the firm are negatively associated with negative skewness, we control for the standard deviation of weekly residual returns (Sigma) and the firm's beta (Beta). Stocks with heightened trading volume are 
more prone to crashes, therefore we control for contemporaneous share turnover (Turnover), measured as the average weekly share turnover in year $t$. As performance could influence the propensity for a stock to crash, we control for market performance (Return), measured as the annual market-adjusted stock return in year $t$. In addition to contemporaneous values of Turnover and Return, we also include lagged measures of these variables to control for momentum and behavioral factors. As firm visibility could also influence incentives to suppress negative financial information, we control for whether or not the firm is covered in the Fortune 500 index in year $t$ (Fortune_500) and analyst following (Log_Analysts), measured as the natural logarithm of the number of analysts issuing annual earnings forecasts for the firm in year $t$.

We also include state as well as industry-by-year fixed effects (two-digit SIC industries interacted with year) to control for idiosyncratic time, state, or industry factors that can influence crash risk. The state fixed effects ensure that our differences are identified from district-todistrict variation among states rather than districts located in different states. The industry-byyear fixed effects absorb all variation between industries in a given year, ensuring our differences are identified from firms in the same industry. We cluster standard errors at the state level to capture variation in standard errors across states. Bertrand, Duflo, and Mullainathan (2004) highlight that the standard errors of OLS estimates in differences-in-differences estimations can severely understate the standard deviation, and thus lead to Type I errors (i.e., detecting an effect that is not present). Given that our setting is characterized by a relative short time series (i.e., 5 years) and a relatively high number of states (i.e., 35 states), clustering at the state level allows us to mitigate the Type I error concern while still allowing for sufficient statistical power. All variables are defined in Appendix A. 
Several features of our research design are worth noting. First, because we examine differences in firm behavior across time, aspects of the congressional district or firm that do not change over time cannot drive the observed change in firm behavior. Second, because we benchmark the behavior of Democratic firms with FNC availability (treatment firms) to Democratic firms without FNC availability (control firms), non-political firms with FNC availability (control firms), and non-political firms without FNC availability (control firms), our research design controls for time-varying effects. For example, to the extent that our sample period coincides with significant macroeconomic events (e.g., the Dotcom bubble, September $11^{\text {th }}$ terrorist attacks, Enron, the passage of SOX and other regulatory changes, etc.), both treatment and control firms should be affected by such events. Finally, the intertemporal (i.e., pre-/post-election) and cross-sectional (i.e., FNC availability and Democratic vs. non-political firm) variation in our setting reduces endogeneity concerns. Given our triple differences research design, unobservable and omitted firm or geographic characteristics would have to affect only Democratic firms, do so differently over time, and be correlated with, but not driven by, FNC.

\subsection{Descriptive statistics}

Table 3 reports descriptive statistics for the variables described above. Panel A presents statistics for the complete pooled sample and the sample of Democratic firms separately. Panel B compares means between sample firms portioned based on FNC availability, both for the pooled sample but also for the Democratic-linked sample. Panel A of Table 3 shows that, in the pooled sample, approximately 2 percent of firms make soft money contributions to the Democratic Party. Within the sample of Democratic firms, 68 percent of the soft money contributions are made to the Democratic Party, with these firms spending on average about $\$ 52,706$. In the pooled sample, approximately 47 percent of firms are headquartered in a district with slanted media outlet availability. In the sample of Democratic firms, approximately 53 percent of firms 
are located in a district with slanted media outlet availability. Democratic firms are on average larger than firms in the pooled sample, which is consistent with firm size being a significant determinant of corporate political activity (Cooper, Gulen, and Ovtchinnikov, 2010). ${ }^{15}$

Columns 1 and 2 of Panel B report differences in means among the large pooled sample of firms, partitioned based on FNC availability. While many of the differences are statistically significant, very few of the differences are economically significant (i.e., firm growth, idiosyncratic risk, performance). Columns 3 and 4 of Panel B report differences in means among the smaller sample of Democratic-linked firms, partitioned based on FNC availability. Treatment firms also have a higher turnover and higher idiosyncratic risk. However, there are no significant differences in any of the other firm characteristics used in our empirical model, suggesting that, by and large, treatment and control firms are comparable. There are also statistically significant but economically small differences in the demographics of districts in which treatment and control firms are located. In particular, in areas where treatment firms are located, the total population is slightly smaller, the household income is somewhat different, and the unemployment rate is slightly higher, potentially raising the concern that systematic differences in the underlying economics across districts in which treatment and control firms are located might affect our inferences. We address these issues in Section $4 .{ }^{16}$

- Please insert Table 3 about here -

\section{Results}

\subsection{Main results}

\footnotetext{
${ }^{15}$ While FNC was available to only $17 \%$ of the U.S. population by June 2000 , about $50 \%$ of our sample firms are headquartered in areas with FNC availability. This is likely explained by the fact that corporate headquarters are geographically clustered in and around major urban centers, most of which had FNC availability by the year 2000.

${ }^{16}$ Online Appendix Table A1 presents the correlation coefficients for our sample firms.
} 
Table 4 shows the results of estimating Equation (1) for our sample firms. We find a negative and significant coefficient on the three-way interaction between Election, FNC and Dem_Firm, and a positive and significant coefficient on the interaction between Post_Election, FNC, and Dem_Firm using both FNC measures. These coefficients are statistically significant at the $10 \%$ level or higher (two-tailed). The coefficient on the sum of these three-way interaction variables is also statistically significant at the $1 \%$ level (two-tailed). The coefficient estimates on the two interaction variables in Column 1 are 0.033 and 0.036 , respectively. The economic magnitudes of these coefficient estimates imply a significant effect as Chen, Hong, and Stein (2001) find that a change in negative skewness of 0.037 yields an economically meaningful increase in the price of put options. The coefficient estimates in Column 2 also imply that the observed difference between treatment and control firms represents an economically meaningful (i.e., approximately one-third standard deviation) reduction in negative stock return skewness during the pre-election period. The subsequent increase in negative stock return skewness in the post-election period is of similar magnitude, consistent with the release of withheld negative financial information. These results indicate that treatment firms located in districts with access to a slanted media outlet suppress negative information prior to the election and subsequently release that information after the election, providing support for our hypothesis. The coefficients on the control variables, where significant, are typically consistent with prior research. ${ }^{17}$

- Please insert Table 4 about here -

\subsection{Cross-sectional test based on firm visibility}

Our theoretical framework maintains that firms are more likely to be responsive to potential reputational costs when their reputation is central to maintaining profitability. This includes firms that have significant external relationships and are more visible (Dyck and

\footnotetext{
${ }^{17}$ In Online Appendix Table A2, we report the sensitivity of our main findings to other fixed effects structures.
} 
Zingales, 2002; Dyck, Volchkova, and Zingales, 2008). Gurun and Butler (2012) find that while slanted coverage by local media outlets disproportionately affects less visible firms, slanted coverage by national media outlets disproportionately affects more visible firms. Given that FNC is a national media outlet, our expectation is that its coverage disproportionately affects more visible firms. Our detailed review of FNC transcripts confirms this expectation. In Panel B of Table 1, the chi-square statistics test the null hypothesis that there is no relation between a firm being headquartered in an area with FNC availability and being a Fortune 500 firm. ${ }^{18}$ The observed number of highly visible firms discussed or interviewed on FNC is significantly higher than the expected number of firms at the $1 \%$ level of statistical significance. Thus, FNC appears to focus disproportionately on large firms (we label this tendency “visibility bias”).

Given this descriptive evidence of FNC's visibility bias and the predictions arising from our theoretical framework, we conduct a cross-sectional test. Table 5 reports the results of a test partitioning our sample based on whether or not the firm is in the Fortune 500. We find evidence consistent with expectations as Election*FNC*Dem_Firm $<0$ and Post_Election*FNC*Dem_Firm $>0$ only for the subsample of firms in the Fortune 500. Thus, the suppress-and-release pattern is concentrated in more visible firms. ${ }^{19}$

- Please insert Table 5 about here -

\subsection{Differences in unobservable firm characteristics}

A potential concern with the results presented thus far is that treatment firms could have unobservable characteristics that drive the news suppression behavior we show. To alleviate the concern that unobservable time-invariant traits of treatment firms drive news suppression, we

\footnotetext{
${ }^{18}$ Table 1 excludes firms headquartered in the 15 states for which we do not have FNC-availability data, explaining the seemingly low number (270) of Fortune 500 firms included in Panel B.

${ }^{19}$ In Online Appendix Table A3, we also present evidence of a visibility bias using analyst coverage as a measure of firm visibility. In Online Appendix Table A4, we partition our sample based on analyst following. We find evidence consistent with expectations as Election*FNC*Dem_Firm $<0$ and Post_Election*FNC*Dem_Firm $>0$ only for the subsample of firms in the top quartile of analyst following.
} 
conduct a falsification test. Specifically, we rerun Equation (1) for the 1996 election. As FNC was first introduced in October 1996 but not available in almost all U.S. households, we can use the 1996 election to examine whether treatment firms located in areas with FNC availability in 2000 behaved similarly during the 1996 election when FNC was not yet available. We run this test for two sets of firms: 1) the sample of firms that contributed to the Democratic Party during the period 1998-2003, and 2) firms that contributed soft money to the Democratic Party during the period 1994-1999. As shown in Table 6, we find that treatment firms located in areas that would eventually have FNC access in 2000 do not suppress negative information and subsequently release such information around the 1996 election. Thus, it is unlikely that unobservable time-invariant firm characteristics of treatment firms explain our results.

- Please insert Table 6 about here -

\subsection{Information access versus slanted information}

Another potential concern with the results presented thus far is that slanted media outlet mainly captures information availability rather than ideological slant in the reporting of this information. Thus, it is possible that our results are driven simply by the availability of an additional news source. We control for this possibility in the regressions described above by benchmarking the behavior of Democratic firms to non-political firms located in areas with FNC access. To further alleviate this concern, we conduct an empirical test. Around the same time as the diffusion of FNC, broadband internet became more prevalent. Access to broadband internet is likely to provide access to more, but not necessarily ideologically slanted information. Thus, we obtain data on internet broadband access from the Center for Policy Informatics and replace our FNC measures with either an Internet indicator, equal to one if the county in which the firm is located had internet access in the particular year, or Share_Internet, which is the ratio of households with broadband internet access per county. We rerun Equation (1) for the same set of 
treatment firms that we use in Table 4. As shown in Online Appendix Table A5, we do not find that treatment firms located in areas with broadband internet access suppress negative information before the election and subsequently release such information after the election. We also include these variables in our main model and continue to observe significant coefficients on our main test variables.

\subsection{Real actions}

We also examine real actions that firms undertake to avoid reputational costs. We focus on real actions that are likely to cause negative media scrutiny during the election: employment and investment reductions. Prior research shows that because current employment and investment levels significantly influence voters, politically connected firms cater to their political allies by avoiding layoffs and plant closures prior to an election (Bertrand, Kramarz, Schoar, and Thesmar, 2007). Hollister (2016) finds that by the mid-1990's, public and media scrutiny over corporate downsizing had reached a level of hysteria, fueled in part by the 1996 election, which brought considerable attention to the issue. Relative to our main tests, these tests allow us to provide evidence on specific types of information that could have been temporarily suppressed.

Prior to elections, treatment firms have particularly strong incentives to avoid announcing workforce reductions given the potential costs that FNC could impose. Similar to Ramanna and Roychowdhury (2010), we maintain that firms have some discretion on the timing of these announcements. For our sample firms, we obtain data on employee dismissal and plant closure notices under the Worker Adjustment and Retraining Notification Act of 1988 (WARN) by U.S. firms. The WARN Act is a U.S. labor law that protects employees, their families, and communities by requiring most employers with 100 or more employees to provide 60 calendarday advance notification of plant closings and mass layoffs of employees. We hand collect the data on WARN notices from various state government websites for our sample period; 
specifically the exact date of the WARN notice and the number of people laid off. These announcements are typically bundled with plant closure announcements and thus jointly capture both activities. ${ }^{20}$ We find that treatment firms announce fewer workforce reductions or plantclosure announcements in terms of the number of announcements as well as the magnitude of workforce reductions prior to the election (see Table 7, Panel A, Columns 1, 2, and 4). In the period after the election, we observe no differential effect for treatment firms.

We also examine whether a similar pattern can be observed in annual financial statement data on employment as well as property, plant, and equipment levels to shed further light on each of the two actions. We conjecture that prior to the election, treatment firms have particularly strong incentives to avoid releasing news on workforce reductions given the potential costs that FNC could impose. Consistent with this prediction, in Table 7, Panel B (Columns 1 and 2), we find that treatment firms are less likely to have large workforce reductions prior to the election. Consistent with our WARN analysis, in the period after the election, we observe no differential effect for treatment firms. As an alternative operational decision, we also examine the likelihood of large reductions in property, plant, and equipment for treatment firms before and after the election. As shown in Table 7, Panel C (Column 1), we find that sample firms are less likely to have large reductions in investments prior to the election if located in an area with FNC access but are more likely to have such reductions after the election. This evidence is consistent with the initial suppression and subsequent release of negative financial information.

$$
\text { - Please insert Table } 7 \text { about here - }
$$

\subsection{Evidence from subsamples with particularly strong economic incentives}

\footnotetext{
${ }^{20}$ WARN notices for plant closures are required when 50 or more full-time workers are laid off due to the shutdown of a single site of employment. WARN notices for mass layoffs are required when 50 or more full-time workers are laid off and these workers represent at least $33 \%$ of the employer's workforce.
} 
Following Knight (2006), we also use reports produced by financial analysts during the 2000 election campaign as an alternative measure to identify firms with ties to the Democratic Party. These reports identify 29 firms likely to fare well under a Gore administration based on the candidate's policy platform. For example, Gore favored price controls and promoted generic pharmaceuticals. Linking firms to the Democratic Party based on policy platforms ensures that we capture firms' economic benefits more directly. ${ }^{21}$ From this sample of 29 firms, we exclude foreign firms, firms headquartered in states without FNC data, and firms without a minimum of five years of financial data. After imposing these constraints, we are left with 16 Democratic firms. The small sample precludes employing our full triple differences research design with state and industry-year fixed effects. While the small sample size and resulting lack of power is a major limitation of this sample, we find results consistent with the results presented in Table 4, as shown in Panel A of Table 8 (Column 1).

We also identify another set of firms whose economic incentives are more affected by the prevailing political landscape. In Table 8, Panel B, we report tests in which we explore whether our suppress-and-release pattern is stronger for firms with significant government contracts. We obtain information on firm-level government contracts from the USAspending.gov website maintained by the Department of Treasury's Bureau of Fiscal Services. The U.S. government publicly discloses detailed information about every transaction of more than $\$ 25,000$. Contract information includes total value, awarded contractor, and granting agency, but does not contain firm identifiers. Thus, we use a machine-learning program to match over 596,000 parent

\footnotetext{
${ }^{21}$ Knight (2006) finds that the equity prices of these politically sensitive firms are substantively affected by the outcome of the election (the results suggest differential returns ranging from $9 \%$ to $16 \%$ ). Thus, with this measure, it is easier to envision treatment firms internalizing the preferences of the Democratic Party. On pp. 769-770 of his paper, Knight also provides descriptive statistics on campaign contributions from these firms. The average level of soft money contributions to the Democratic Party reported by Knight (2006) is very similar to ours (i.e., about $\$ 55,000)$. Thus, even though the average soft money contributions appear to be small, soft money contributions are correlated with substantial economic benefits.
} 
company names to the names of our sample companies. We verify the reasonableness of the matching using Compustat Segment data on major customers. As reported in Table 8, Panel B, we partition our sample based on whether or not the firm is a significant government contractor (defined as a firm deriving at least 25 percent of its revenues from government contracts). In Columns 1 and 2, Election*FNC*Dem_Firm $<0$ and Post_Election*FNC*Dem_Firm $>0$ for both subsamples, but the differences are statistically significant in the direction predicted. Consistent with our expectations, government contractors show stronger evidence of the suppress-and-release pattern.

\subsection{Additional robustness tests}

- Please insert Table 8 about here -

We conduct a series of additional untabulated robustness tests. First, we rerun Equation (1) using a sample of firms that are geographically concentrated in their headquarter state. This analysis helps to reduce concerns that because firms operate in multiple states and countries, developments in local media markets are not particularly relevant. We follow Dyreng and Lindsey (2009) and identify the locations of firms’ subsidiaries using Exhibit 21 of Form 10-K. We define locally concentrated treatment firms as those firms with less than 25 subsidiaries outside of their headquarter state. Our results using this reduced sample of geographically

concentrated firms are similar to the results reported in Table 4. Second, we control for a commonly used measure of sensitivity to policy uncertainty to rule out the possibility that our results can be explained by election related uncertainty altering firm behavior. We include the political alignment index of Kim, Pantzalis, and Park (2012) as an additional control variable for policy uncertainty and find that our results are robust. Third, as we have data on FNC access as of 1998, 2000, and 2003, in an additional robustness test we assume the same FNC access in 2003 (our last year) as in 2000 to hold the firms with FNC access constant. The results are 
robust. Fourth, an additional concern is that we keep firm-year observations for fiscal year 2000. For these firms, part of their operations overlap with the pre- and post-election period. Thus, we rerun Equation (1) excluding all observations for fiscal year 2000. The results are robust.

\section{Conclusions}

In the spirit of Dyck and Zingales (2002) and Dyck, Volchkova, and Zingales (2008), we propose that the media plays a significant role in shaping firms' reputational capital. As such, we expect firms actively follow developments in media markets and alter their behavior to maximize reputational capital. In particular, we maintain that firms attempt to minimize the costs of bad news revelation as such news has the potential to decrease firms' reputational capital.

We exploit the geographical variation in availability of Fox News Channel to more confidently isolate the media's effect on firm decisions. We also anchor our analysis around the 2000 presidential election to identify time-series variation in the costs of bad news revelation. Using a triple differences research design, we find that treatment firms report less negative financial information during periods of higher media scrutiny. These results are concentrated among more visible firms, who have particularly strong incentives to manage reputational capital.

Our evidence suggests that developments in media markets can influence the behavior of economic agents in financial markets. We focus on a media source with a well-understood ability to negatively frame news coverage. Media slant represents a wide-spread and long-standing feature of the information environment in the U.S., yet we have limited evidence on its effects. Our findings complement prior media studies by shedding light on the anticipatory actions firms can take to maximize their reputational capital in light of a changing media environment. 


\section{Appendix A \\ Variable definitions.}

\begin{tabular}{l|l}
\hline Variable & Description \\
\hline Primary Dependent Variable & \multicolumn{2}{|l}{$\begin{array}{l}\text { Following Chen, Hong, and Stein (2001) and Jin and Myers (2006), Ncskew is } \\
\text { measured as the third moment of each stock's weekly residual returns, divided } \\
\text { by the cubed standard deviation of weekly residual returns, times negative } \\
\text { one, in year } t .\end{array}$} \\
\hline
\end{tabular}

\section{Alternative Dependent Variables}

Announced_Reductions

The sum of the number of employees firms announced to layoff per year. The announcements are obtained from Worker Adjustment and Retraining Notification Act of 1988 (WARN) notices.

The sum of the number of firms' workforce-reduction or plant-closure

Number_Announcements announcements per year. The announcements are obtained from WARN notices.

One if a firm's change in number of employees relative to the average number

Workforce_Reduction of employees employed is in the top quarter of the distribution, zero otherwise.

Investment_Reduction

One if a firm's change in gross PP\&E relative to the average level of PP\&E employed is in the top quarter of the distribution, zero otherwise.

\begin{tabular}{|c|c|}
\hline \multicolumn{2}{|c|}{ Political Connections Variables } \\
\hline Soft_Money_Contributor & $\begin{array}{l}\text { One if a firm's soft money contributions as reported in the Center for } \\
\text { Responsive Politics (CRP) data set are greater than } 0 \text {, zero otherwise. }\end{array}$ \\
\hline Soft_Money_Dem & $\begin{array}{l}\text { A firm's soft money contributions to the Democratic Party as reported in the } \\
\text { CRP data set. }\end{array}$ \\
\hline Share_Dem & $\begin{array}{l}\text { The percentage of a firm's soft money contributions allocated to the } \\
\text { Democratic Party. }\end{array}$ \\
\hline Dem_Firm & $\begin{array}{l}\text { One if a firm is a soft money contributor to the Democratic Party as reported } \\
\text { in the CRP data set, and zero otherwise. }\end{array}$ \\
\hline \multicolumn{2}{|l|}{ Election Variables } \\
\hline Election & $\begin{array}{l}\text { One if a firm's fiscal year end falls in the time period July 31, } 1999 \text { to June 30, } \\
\text { 2000, zero otherwise. }\end{array}$ \\
\hline Post_Election & $\begin{array}{l}\text { One if a firm's fiscal year end falls in the time period July 31, } 2001 \text { to June 30, } \\
\text { 2002, zero otherwise. }\end{array}$ \\
\hline \multicolumn{2}{|l|}{ Fox News Variables } \\
\hline FNC_Subscriptions & $\begin{array}{l}\text { The natural logarithm of the number of Fox News Channel subscriptions per } \\
\text { congressional district. We obtained data on Fox News Channel subscriptions } \\
\text { from Joshua Clinton and Ted Enamorado. }\end{array}$ \\
\hline FNC_Indicator & $\begin{array}{l}\text { One if Fox News Channel is available in a particular district, zero otherwise. } \\
\text { We obtained data on Fox News Channel availability from Joshua Clinton and } \\
\text { Ted Enamorado. }\end{array}$ \\
\hline \multicolumn{2}{|l|}{ Firm Visibility Variables } \\
\hline Fortune_500 & One if the firm is covered in the Fortune 500 index as reported in Compustat, \\
\hline
\end{tabular}


zero otherwise.

Natural logarithm of the number of analysts issuing annual earnings forecasts

Log_Analysts

for firms covered by IBES. Set equal to zero if the firm is not covered by IBES.

\section{Control Variables}

\begin{tabular}{|c|c|}
\hline Log_Mark_Cap & $\begin{array}{l}\text { The natural log of market capitalization, calculated as shares outstanding at } \\
\text { fiscal year-end (CSHO) times the share price at fiscal year-end (PRCC_F) as } \\
\text { reported in Compustat. }\end{array}$ \\
\hline Chg_Sales & $\begin{array}{l}\text { The percentage change in annual sales (REVT) as reported in Compustat from } \\
\text { year } t-1 \text { to year } t \text {. }\end{array}$ \\
\hline Sigma & The standard deviation of weekly excess return in year $t$. \\
\hline Turnover & The average weekly share turnover in year $t$. \\
\hline Lag_Turnover & The lagged average weekly share turnover in year $t$. \\
\hline Beta & A firm's beta; estimated using weekly returns in year $t$. \\
\hline Return & A firm’s annual market-adjusted stock return in year $t$. \\
\hline Lag_Return & A firm’s lagged annual market-adjusted stock return in year $t$. \\
\hline Population & Population per congressional district as per the U.S. Census Bureau. \\
\hline Household_Income & Household income per congressional district as per the U.S. Census Bureau. \\
\hline Unemployment_Rate & Unemployment rate per congressional district as per the U.S. Census Bureau. \\
\hline Loss & One if a firm's return on assets is smaller than zero, zero otherwise. \\
\hline
\end{tabular}




\section{References}

Apollonio, D.E., Raja, R.J.L., 2004. Who gave soft money? the effect of interest group resources on political contributions. Journal of Politics 66, 1134-1154.

Auletta, K., 2001. The Microsoft Verdict, The New Yorker. Available at: http://www.newyorker.com/magazine/2001/07/09/the-microsoft-verdict.

Ayers, B.C., Ramalingegowda, S., Yeung, P.E., 2011. Hometown advantage: the effects of monitoring institution location on financial reporting discretion. Journal of Accounting and Economics 52, 41-61.

Baloria, V.P., Klassen, K.J., 2017. Supporting tax policy change through accounting discretion: evidence from the 2012 elections. Management Science Forthcoming.

Baron, D.P., 2006. Persistent media bias. Journal of Public Economics 90, 1-36.

Bertrand, M., Kramarz, F., Schoar, A., Thesmar, D., 2007. Politicians, firms and the political business cycle: evidence from France. Unpublished working paper. University of Chicago.

Bertrand, M., Duflo, E., Mullainathan, S., 2004. How much should we trust differences-indifferences estimates? Quarterly Journal of Economics 119, 249-275.

Besley, T., Prat, A., 2006. Handcuffs for the grabbing hand? media capture and government accountability. American Economic Review 96, 720-736.

Bushee, B.J., Core, J.E., Guay, W., Hamm, S.J., 2010. The role of the business press as an information intermediary. Journal of Accounting Research 48, 1-19.

Chen, J., Hong, H., Stein, J.C., 2001. Forecasting crashes: trading volume, past returns, and conditional skewness in stock prices. Journal of Financial Economics 61, 345-381.

Chhaochharia, V., Kumar, A., Niessen-Ruenzi, A., 2012. Local investors and corporate governance. Journal of Accounting and Economics 54, 42-67.

Clinton, J.D., Enamorado, T., 2014. The national news media's effect on congress: how fox news affected elites in congress. Journal of Politics 76, 928-943.

Cooper, M.J., Gulen, H., Ovtchinnikov, A.V., 2010. Corporate political contributions and stock returns. Journal of Finance 65, 687-724.

Core, J.E., Guay, W., Larcker, D.F., 2008. The power of the pen and executive compensation. Journal of Financial Economics 88, 1-25.

Dai, L., Parwada, J.T., Zhang, B., 2015. The governance effect of the media's news dissemination role: evidence from insider trading. Journal of Accounting Research 53, 331-366. 
DellaVigna, S., Kaplan, E., 2007. The fox news effect: media bias and voting. Quarterly Journal of Economics 122, 1187-1234.

Dougal, C., Engelberg, J., Garcia, D., Parsons, C.A., 2012. Journalists and the stock market. Review of Financial Studies 25, 639-679.

Drake, M.S., Guest, N.M., Twedt, B.J., 2014. The media and mispricing: the role of the business press in the pricing of accounting information. The Accounting Review 89, 1673-1701.

Dyck, A., Zingales, L., 2002. The governance role of the media. In Islam, R. (Ed.), The right to tell: the role of mass media in economic development, The World Bank, Washington, pp. 107-40 (Chapter 7).

Dyck, A., Volchkova, N., Zingales, L., 2008. The corporate governance role of the media: evidence from Russia. Journal of Finance 63, 1093-1135.

Dyck, A., Morse, A., Zingales, L., 2010. Who blows the whistle on corporate fraud? Journal of Finance 65, 2213-2253.

Dyreng, S.D., Lindsey, B.P., 2009. Using financial accounting data to examine the effect of foreign operations located in tax havens and other countries on U.S. multinational firms' tax rates. Journal of Accounting Research 47, 1283-1316.

Engelberg, J.E., Parsons, C.A., 2011. The causal impact of media in financial markets. Journal of Finance 66, 67-97.

Faccio, M., Masulis, R.W., McConnell, J.J., 2006. Political connections and corporate bailouts. Journal of Finance 61, 2597-2635.

Fang, L.H., Peress, J., 2009. Media coverage and the cross-section of stock returns. Journal of Finance 64, 2023-2052.

Gentzkow, M., Shapiro, J.M., 2010. What drives media slant? evidence from U.S. daily newspapers. Econometrica 78, 35-71.

Gerber, A., Karlan, D., Bergan, D., 2009. Does the media matter? a field experiment measuring the effects of newspaper on voting behavior and political opinions. American Economic Journal: Applied Economics 1, 35-52.

Groseclose, T., Milyo, J., 2005. A measure of media bias. Quarterly Journal of Economics 120, 1191-1237.

Gurun, U.G., Butler, A.W., 2012. Don't believe the hype: local media slant, local advertising, and firm value. Journal of Finance 67, 561-598.

Hollister, M., 2016. Speaking of downsizing: the use of the term "downsizing" in american news media 1975-2007. Unpublished working paper. McGill University. 
Hopkins, D.J., Ladd, J.M., 2014. The consequences of broader media choice: evidence from the expansion of fox news. Quarterly Journal of Political Science 9, 115-135.

Hutton, I., Jiang, D., Kumar, A., 2015. Political values, culture, and corporate litigation. Management Science 61, 2905-2925.

Jayachandran, S., 2006. The jeffords effect. Journal of Law and Economics 49, 397-425.

Jensen, M.C., 1979. Toward a theory of the press. In Economics and Social Institutions, edited by K. Brunner. Boston, MA: Martinus Nijhoff: 267-287.

Jin, L., Myers, S.C., 2006. R 2 around the world: new theory and new tests. Journal of Financial Economics 79, 257-292.

Joe, J., Louis, H., Robinson, D., 2009. Managers’ and investors' responses to media exposure of board ineffectiveness. Journal of Financial and Quantitative Analysis 44, 579-605.

Kim, C., Pantzalis, C., Park, J., 2012. Political geography and stock returns: the value and risk implications of proximity of political power. Journal of Financial Economics 106, 196-228.

Knight, B., 2006. Are policy platforms capitalized into equity prices? evidence from the Bush/Gore 2000 presidential election. Journal of Public Economics 90, 751-773.

Kuhnen, C.M., Niessen, A., 2012. Public opinion and executive compensation. Management Science 58, 1249-1272.

Liu, B., McConnell, J.J., 2013. The role of the media in corporate governance: do the media influence managers' capital allocation decisions. Journal of Financial Economics 110, 117.

McConnell, J.J., Muscarella, C.J., 1985. Corporate capital expenditure decisions and the market value of the firm. Journal of Financial Economics 14, 399-422.

Miller, G.S., 2006. The press as a watchdog for accounting fraud. Journal of Accounting Research 44, 1001-1033.

Miller, G.S., Skinner, D.J., 2015. The evolving disclosure landscape: how changes in technology, the media, and capital markets are affecting disclosure. Journal of Accounting Research 53, 221-239.

Milyo, J., Primo, D., Groseclose, T., 2000. Corporate PAC campaign contributions in perspective. Business and Politics 2, 75-88.

Mullainathan, S., Shleifer, A., 2005. The market for news. American Economic Review 95, 1031-1053.

Peress, J., 2014. The media and the diffusion of information in financial markets: evidence from 
newspaper strikes. Journal of Finance 69, 2007-2043.

Piotroski, J.D., Wong, T., Zhang, T., 2015. Political incentives to suppress negative information: evidence from Chinese listed firms. Journal of Accounting Research 53, 405-459.

Ramanna, K., Roychowdhury, S., 2010. Elections and discretionary accruals: evidence from 2004. Journal of Accounting Research 48, 445-475.

Reuter, J., Zitzewitz, E., 2005. Do ads influence editors? Advertising and bias in the financial media. Quarterly Journal of Economics 121, 197-227.

Rogers, J.L., Skinner, D.J., Zechman, S.L., 2016. The role of the media in disseminating insidertrading news. Review of Accounting Studies 21, 711-739. 


\section{Figure 1}

FNC availability in 2000.

This figure shows FNC availability in 2000. We obtained this figure from Clinton and Enamorado (2014).

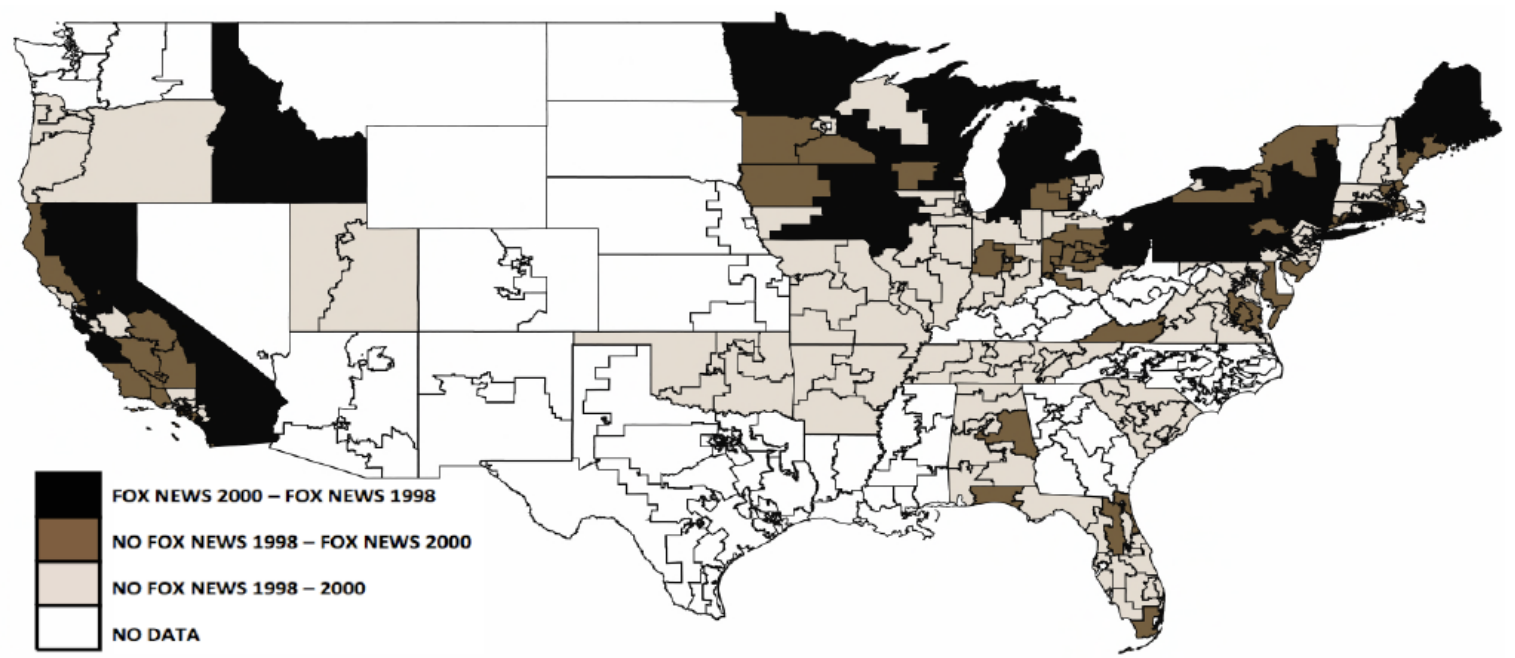




\section{Figure 2}

Empirical design around 2000 election.

This figure shows the design of our empirical tests around the 2000 election, which employs a triple differences design along two cross-sectional (i.e., Firms located in areas with and without FNC, and Democratic-linked vs. non-political firms) as well as an intertemporal (i.e., pre- and post-election) dimension.

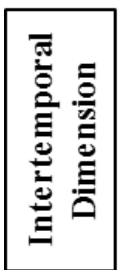

Election

Election Date: November 7, 2000
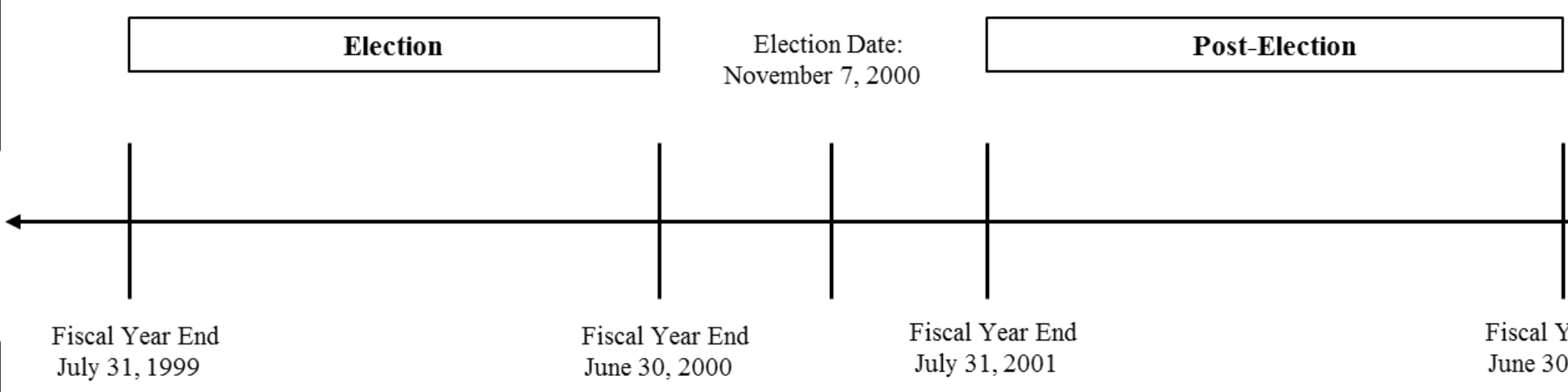

Firms in areas with FNC (Treatment)

Firms in areas without FNC (Control)
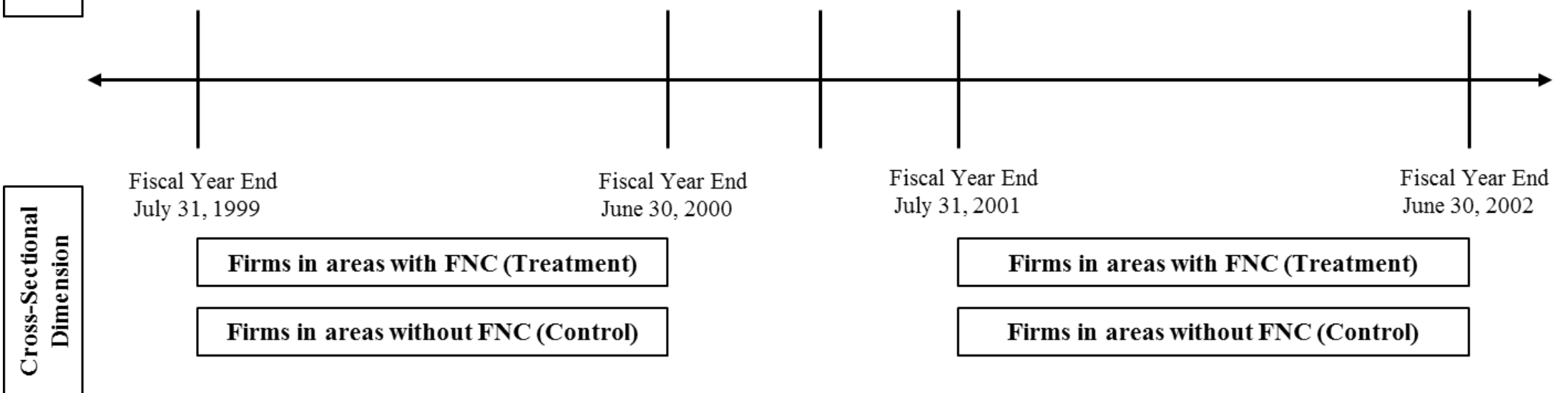

Fiscal Year End 31,1999

Firms in areas with FNC (Treatment)

Firms in areas without FNC (Control)

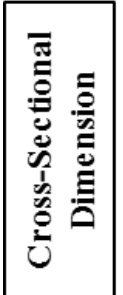

Democratic-Linked Firms (Treatment)

Democratic-Linked Firms (Treatment)

Non-Political Firms (Control)

Non-Political Firms (Control) 


\section{Table 1}

Association between firms covered on fox news channel and full sample in 2000.

The table presents results of chi-square tests of the null hypothesis that there is no relation between the sample partitions and coverage on Fox News Channel in the year 2000. In Column 1, firms that are covered on the "Cavuto Business Report", "Fox News Sunday", "Special Report with Brit Hume”, and "The O'Reilly Factor") in 2000 are tabulated, and, in Column 2, firms that are not covered in those shows are tabulated. In Panel A, FNC-access firms refer to those firms located in areas with FNC access in 2000; no-FNC-access firms are those located in areas without FNC access in 2000. In Panel B, Fortune 500 firms appear in the Fortune_500 cell, and in the No Fortune_500 cell otherwise. The chi-square test statistic measures the divergence of the observed data from the values that would be expected under the null hypothesis of no association, where the expected values for each cell [in brackets] in the two-way tables is equal to (row total*column total)/number of total observations. $p$-values (twotailed) are presented beneath the chi-square statistic within parenthesis. *,**,*** represent significance at the 10, 5, and 1 percent level, respectively.

\begin{tabular}{lccc}
\hline \multicolumn{3}{c}{ Covered on FNC } & Not Covered on FNC \\
\hline Panel A: FNC access in 2000 & $(1)$ & $(2)$ & \\
\hline FNC access in 2000 & & & 1,948 \\
No FNC access in 2000 & $53[43]$ & $1,895[1,905]$ & 2,175 \\
& $37[47]$ & $2,138[2,128]$ & 4,123 \\
Chi-square statistic & 90 & 4,033 & $5.003^{* *}$ \\
& & & $(0.025)$ \\
\hline Panel B: Fortune 500 & & & 270 \\
\hline Fortune_500 & $30[6]$ & $240[264]$ & 3,853 \\
No Fortune_500 & $60[84]$ & $3,793[3,769]$ & 4,123 \\
& 90 & 4,033 & $107.861^{* * *}$ \\
Chi-square statistic & & & $(0.000)$ \\
\hline
\end{tabular}




\section{Table 2}

Sample selection.

The table displays the sample selection over the period 1998-2003.

\begin{tabular}{lcc}
\hline & Firm-years & Firms \\
\hline Firm(-years) with Compustat and CRSP identifiers 1998-2003 & 38,103 & 9,354 \\
Less: Firm(-years) with missing data & 5,959 & 1,298 \\
Less: Firm(-years) of cross-listed firms & 3,756 & 987 \\
Less: Firm(-years) without data on FNC availability & 9,739 & 2,244 \\
Sample of firms & 18,649 & 4,825 \\
Less: Firm(-years) of firms with political contributions to Republican & 1,019 & 227 \\
Party only & & 4,412 \\
Final sample for Equation (1) & 16,960 & 186 \\
Firm(-years) of firms with soft money contributions to Democratic & 670 & \\
Party in final sample & & \\
\hline
\end{tabular}




\section{Table 3}

Descriptive statistics.

The table shows the summary statistics for all variables used in Equation (1) over the period 1998-2003. Panel A shows statistics for the pooled sample and Democratic-linked sample separately. Panel B shows means separately for treatment and control firms based on FNC availability. Panel B also displays the differences between the means of the variables. ${ }^{*}, * *, * *$ represent significance at the 10,5 , and 1 percent level, respectively. Appendix A presents variable definitions.

Panel A: Pooled samples

All Firms (N=16,960) Democratic-linked Firms (N=670)

\begin{tabular}{lcccccc}
\hline Variable & Mean & Std. & Median & Mean & Std. & Median \\
\hline Soft_Money_Contributor & 0.021 & 0.142 & 0 & 1 & 0 & 1 \\
Soft_Money_Dem & 716 & 13,808 & 0 & 52,706 & 85,749 & 19,000 \\
Share_Dem & 0.017 & 0.127 & 0 & 0.675 & 0.352 & 0.847 \\
FNC_Indicator & 0.474 & 0.499 & 0 & 0.531 & 0.500 & 1 \\
Ncskew & -0.138 & 1.195 & -0.190 & 0.059 & 1.296 & -0.118 \\
Log_Mark_Cap & 5.008 & 1.971 & 4.924 & 7.494 & 2.176 & 7.669 \\
Chg_Sales & 0.024 & 0.929 & -0.061 & 0.070 & 0.874 & -0.052 \\
Sigma & 0.046 & 0.029 & 0.039 & 0.031 & 0.018 & 0.026 \\
Turnover & 0.128 & 0.146 & 0.076 & 0.147 & 0.139 & 0.098 \\
Lag_Turnover & 0.130 & 0.167 & 0.076 & 0.140 & 0.139 & 0.091 \\
Beta & 0.706 & 0.639 & 0.586 & 0.825 & 0.620 & 0.702 \\
Return & 0.163 & 1.218 & -0.054 & 0.168 & 0.988 & 0.024 \\
Lag_Return & 0.079 & 1.109 & -0.102 & 0.187 & 1.414 & 0.014 \\
Fortune_500 & 0.040 & 0.195 & 0 & 0.406 & 0.491 & 0 \\
Log_Analyst & 1.028 & 0.951 & 1.099 & 2.027 & 1.059 & 2.303 \\
Population & 633,940 & 57,442 & 624,306 & 621,883 & 50,903 & 619,968 \\
Household_Income & 52,252 & 12,968 & 50,346 & 51,655 & 13,639 & 49,399 \\
Unemployment_Rate & 0.048 & 0.011 & 0.049 & 0.050 & 0.012 & 0.052 \\
\hline
\end{tabular}




\begin{tabular}{|c|c|c|c|c|c|c|}
\hline \multirow{3}{*}{ Variable } & \multicolumn{3}{|c|}{ All Firms $(\mathrm{N}=16,960)$} & \multicolumn{3}{|c|}{ Democratic-linked Firms $(\mathrm{N}=670)$} \\
\hline & $\begin{array}{l}\text { Treatment Firms } \\
(\mathrm{N}=8,289)\end{array}$ & $\begin{array}{c}\text { Control Firms } \\
(\mathrm{N}=8,671)\end{array}$ & \multirow{2}{*}{$\begin{array}{l}\text { Difference } \\
\text { (1) - (2) }\end{array}$} & $\begin{array}{c}\text { Treatment Firms } \\
\qquad(\mathrm{N}=356)\end{array}$ & $\begin{array}{l}\text { Control Firms } \\
(\mathrm{N}=314)\end{array}$ & \multirow{2}{*}{$\begin{array}{c}\text { Difference } \\
(3)-(4)\end{array}$} \\
\hline & Mean (1) & Mean (2) & & Mean (3) & Mean (4) & \\
\hline Soft_Money_Dem & 956 & 500 & $456^{* * *}$ & 67,181 & 35,925 & $31,256 * * *$ \\
\hline Ncskew & -0.147 & -0.131 & -0.016 & 0.054 & 0.064 & -0.010 \\
\hline Log_Mark_Cap & 5.090 & 4.935 & $0.155^{* * *}$ & 7.620 & 7.379 & 0.241 \\
\hline Chg_Sales & 0.005 & 0.041 & $-0.036 * *$ & 0.085 & 0.087 & -0.002 \\
\hline Sigma & 0.045 & 0.046 & $-0.001 * * *$ & 0.030 & 0.031 & -0.001 \\
\hline Turnover & 0.139 & 0.125 & $0.014 * * *$ & 0.150 & 0.142 & 0.008 \\
\hline Lag_Turnover & 0.136 & 0.125 & $0.011 * * *$ & 0.151 & 0.127 & $0.024 * *$ \\
\hline Beta & 0.752 & 0.662 & $0.090 * * *$ & 0.882 & 0.772 & $0.110^{* *}$ \\
\hline Return & 0.212 & 0.119 & $0.093 * * *$ & 0.211 & 0.105 & 0.106 \\
\hline Lag_Return & 0.105 & 0.058 & $0.047 * * *$ & 0.229 & 0.138 & 0.091 \\
\hline Fortune_500 & 0.044 & 0.046 & -0.002 & 0.412 & 0.411 & 0.001 \\
\hline Log_Analyst & 1.049 & 1.062 & -0.013 & 2.062 & 2.010 & 0.052 \\
\hline Population & 625,402 & 641,687 & $-16,285^{* * *}$ & 614,723 & 631,093 & $-16,370 * * *$ \\
\hline Household_Income & 52,827 & 51,730 & $-1,457 * * *$ & 50,667 & 52,842 & $-2,175^{*}$ \\
\hline Unemployment_Rate & 0.053 & 0.044 & $0.009 * * *$ & 0.052 & 0.048 & $0.004^{* *}$ \\
\hline
\end{tabular}




\section{Table 4}

Slanted media outlet availability and news suppression.

The table presents results on the relation between slanted media outlet availability and news suppression around the 2000 election. The dependent variable in all models is Ncskew, which is a firm's third moment of excess daily stock returns scaled by its cubed standard deviation times minus one. In Column 1, FNC is measured as the natural logarithm of the number of Fox News Channel subscriptions per congressional district, denoted FNC_Subscriptions. In Column 2, FNC is an indicator equal to one if Fox News Channel was available in a particular congressional district, and zero otherwise, denoted FNC_Indicator. All models span the period 1998-2003. The results reported are from an OLS estimation and use the sample of firms as defined in Table 2. The models include state as well as industry-by-year fixed effects. Standard errors are clustered by state. $p$-values (two-tailed) are displayed in parentheses below the coefficient estimates. *,**,*** represent significance at the 10,5 , and 1 percent level, respectively. Appendix A presents variable definitions.

\begin{tabular}{|c|c|c|c|}
\hline & & $\begin{array}{c}\text { FNC }= \\
\text { FNC_Subscriptions }\end{array}$ & $\begin{array}{c}\text { FNC }= \\
\text { FNC_Indicator }\end{array}$ \\
\hline & & (1) & (2) \\
\hline Variables & Pred. & Ncskew & Ncskew \\
\hline \multirow[t]{2}{*}{ FNC } & & $0.004 * *$ & $0.035^{*}$ \\
\hline & & $(0.02)$ & $(0.07)$ \\
\hline \multirow[t]{2}{*}{ Election } & & $-0.172^{* * *}$ & $-0.180 * * *$ \\
\hline & & $(0.01)$ & $(0.01)$ \\
\hline \multirow[t]{2}{*}{ Election x FNC } & & $-0.007 * * *$ & -0.050 \\
\hline & & $(0.01)$ & $(0.15)$ \\
\hline \multirow[t]{2}{*}{ Dem_Firm } & & -0.028 & -0.027 \\
\hline & & $(0.88)$ & $(0.86)$ \\
\hline \multirow[t]{2}{*}{ Election x Dem_Firm } & & 0.039 & 0.091 \\
\hline & & $(0.86)$ & $(0.68)$ \\
\hline \multirow[t]{2}{*}{ FNC x Dem_Firm } & & 0.001 & 0.064 \\
\hline & & $(0.96)$ & $(0.74)$ \\
\hline \multirow[t]{2}{*}{ Election x FNC x Dem_Firm } & - & $-0.033^{*}$ & $-0.450 * *$ \\
\hline & & $(0.10)$ & $(0.06)$ \\
\hline \multirow[t]{2}{*}{ Post_Election } & & -0.805 & -0.803 \\
\hline & & $(0.23)$ & $(0.23)$ \\
\hline \multirow[t]{2}{*}{ Post_Election x FNC } & & -0.008 & $-0.096^{*}$ \\
\hline & & $(0.11)$ & $(0.05)$ \\
\hline \multirow[t]{2}{*}{ Post_Election x Dem_Firm } & & -0.193 & -0.222 \\
\hline & & $(0.28)$ & $(0.22)$ \\
\hline \multirow[t]{2}{*}{ Post_Election x FNC x Dem_Firm } & + & $0.036 * *$ & $0.426^{*}$ \\
\hline & & $(0.02)$ & $(0.06)$ \\
\hline \multirow[t]{2}{*}{ Log_Mark_Cap } & & $-0.047 * * *$ & $-0.046 * * *$ \\
\hline & & $(0.01)$ & $(0.01)$ \\
\hline \multirow[t]{2}{*}{ Chg_Sales } & & -0.002 & -0.002 \\
\hline & & $(0.80)$ & $(0.78)$ \\
\hline Sigma & & $-5.918^{* * *}$ & $-5.913 * * *$ \\
\hline
\end{tabular}




\begin{tabular}{lcc} 
& $(0.01)$ & $(0.01)$ \\
Beta & -0.013 & -0.014 \\
Turnover & $(0.53)$ & $(0.52)$ \\
& $0.086^{* * *}$ & $0.086^{* * *}$ \\
Lag_Turnover & $(0.01)$ & $(0.01)$ \\
& $-0.052^{* * *}$ & $-0.052^{* * *}$ \\
Return & $(0.01)$ & $(0.01)$ \\
& $-0.132^{* * *}$ & $-0.132^{* * *}$ \\
Lag_Return & $(0.01)$ & $(0.01)$ \\
& $0.023^{* * *}$ & $0.024^{* * *}$ \\
Fortune_500 & $(0.01)$ & $(0.01)$ \\
& -0.036 & -0.036 \\
Log_Analyst & $(0.56)$ & $(0.56)$ \\
& $0.260^{* * *}$ & $0.260^{* * *}$ \\
Constant & $(0.01)$ & $(0.01)$ \\
Test: (Post_Election x FNC x Dem_Firm) - & 0.225 & 0.228 \\
(Election x FNC x Dem_Firm) $>0$ & $(0.72)$ & $(0.72)$ \\
& & \\
Observations & $p=<0.001 * * *$ & $p=<0.001 * * *$ \\
R-square & & 16,960 \\
\hline
\end{tabular}




\section{Table 5}

Cross-sectional tests on firm visibility using Fortune 500 membership.

The table presents results on the relation between slanted media outlet availability and news suppression around the 2000 election. The dependent variable in all models is Ncskew, which is a firm's third moment of excess daily stock returns scaled by its cubed standard deviation times minus one. In Columns 1 and 2 , FNC is measured as the natural logarithm of the number of Fox News Channel subscriptions per congressional district, denoted FNC_Subscriptions. In Columns 3 and 4, FNC is an indicator equal to one if Fox News Channel was available in a particular congressional district, and zero otherwise, denoted FNC Indicator. The models are run separately for firms with (Columns 1 and 3) and without (Columns 2 and 4) Fortune 500 membership. All models span the period 1998-2003. The results reported are from an OLS estimation and use the sample of firms as defined in Table 2. The models include main effects, double interactions, control variables (the same as in Table 4, i.e., Log_Mark_Cap, Chg_Sales, Sigma, Beta, Turnover, Lag_Turnover, Return, Lag_Return, Fortune_500, Log_Analyst), and state as well as industry-by-year fixed effects. Standard errors are clustered by state. $p$-values (two-tailed) are displayed in parentheses below the coefficient estimates. ${ }^{*}, * * * *$ represent significance at the 10,5 , and 1 percent level, respectively. Appendix A presents variable definitions.

\begin{tabular}{|c|c|c|c|c|c|c|c|}
\hline & & \multicolumn{2}{|c|}{ Fortune 500} & \multicolumn{4}{|c|}{ Fortune 500} \\
\hline & & Yes & No & & Yes & No & \\
\hline & & $\begin{array}{c}\text { FNC }= \\
\text { FNC_Subscriptions }\end{array}$ & $\begin{array}{c}\text { FNC }= \\
\text { FNC_Subscriptions }\end{array}$ & & $\begin{array}{c}\mathrm{FNC}= \\
\text { FNC_Indicator }\end{array}$ & FNC = FNC_Indicator & \\
\hline Variables & Pred. & $\begin{array}{c}\text { (1) } \\
\text { Ncskew }\end{array}$ & $\begin{array}{c}(2) \\
\text { Ncskew } \\
\end{array}$ & $\begin{array}{l}\text { Difference } \\
(1)-(2)\end{array}$ & $\begin{array}{c}\text { (3) } \\
\text { Ncskew } \\
\end{array}$ & $\begin{array}{c}(4) \\
\text { Ncskew }\end{array}$ & $\begin{array}{c}\text { Difference } \\
(3)-(4)\end{array}$ \\
\hline Election x FNC x Dem_Firm & - & $\begin{array}{c}-0.114^{* * *} \\
(0.01)\end{array}$ & $\begin{array}{l}-0.015 \\
(0.49)\end{array}$ & $-0.099 * *$ & $\begin{array}{c}-1.504^{* * *} \\
(0.01)\end{array}$ & $\begin{array}{l}-0.296 \\
(0.28)\end{array}$ & $-1.208 * *$ \\
\hline Post_Election x FNC x Dem_Firm & + & $\begin{array}{c}0.263^{* * *} \\
(0.01)\end{array}$ & $\begin{array}{c}0.033^{* *} \\
(0.05)\end{array}$ & $0.230 * *$ & $\begin{array}{l}2.778 * \\
(0.08)\end{array}$ & $\begin{array}{c}0.470 * \\
(0.07)\end{array}$ & $2.308 * * *$ \\
\hline $\begin{array}{l}\text { Test: (Post_Election x FNC x } \\
\text { Dem_Firm) }-(\text { Election x FNC x } \\
\text { Dem_Firm })>0\end{array}$ & & $p=<0.001^{* * *}$ & $p=0.01^{* *}$ & & $p=0.01^{* *}$ & $p=<0.001^{* * *}$ & \\
\hline Observations & & 802 & 16,158 & & 802 & 16,158 & \\
\hline R-square & & 0.473 & 0.139 & & 0.472 & 0.139 & \\
\hline
\end{tabular}




\section{Table 6}

Placebo test: the 1996 election.

The table presents results on the relation between slanted media outlet availability and news suppression around the 1996 election. The dependent variable in all models is Ncskew, which is a firm's third moment of excess daily stock returns scaled by its cubed standard deviation times minus one. In Columns 1 and 3, FNC is measured as the natural logarithm of the number of Fox News Channel subscriptions per congressional district, denoted FNC_Subscriptions. In Columns 2 and 4, FNC is an indicator equal to one if Fox News Channel was available in a particular congressional district, and zero otherwise, denoted FNC_Indicator. Columns 1 and 2 use firms in the period 1994-1999. Columns 3 and 4 use the same sample of firms as described in Table 2. All models span the period 1994-1999. The results reported are from an OLS estimation. The models include main effects, double interactions, control variables (the same as in Table 4, i.e., Log_Mark_Cap, Chg_Sales, Sigma, Beta, Turnover, Lag_Turnover, Return, Lag_Return, Fortune_500,_Log_Analyst), and state as well as industry-by-year fixed effects. Standard errors are clustered by state. $p$-values (two-tailed) are displayed in parentheses below the coefficient estimates. $*, * *, * *$ represent significance at the 10,5 , and 1 percent level, respectively. Appendix A presents variable definitions.

\begin{tabular}{|c|c|c|c|c|}
\hline & $\begin{array}{c}\text { FNC }= \\
\text { FNC_Subscripti } \\
\text { ons } \\
\end{array}$ & $\begin{array}{c}\text { FNC }= \\
\text { FNC_Indicator }\end{array}$ & $\begin{array}{c}\text { FNC }= \\
\text { FNC_Subscription } \\
\text { s } \\
\end{array}$ & $\begin{array}{c}\text { FNC }= \\
\text { FNC_Indicator }\end{array}$ \\
\hline & $(1)$ & (2) & (3) & (4) \\
\hline Variables & Ncskew & Ncskew & Ncskew & Ncskew \\
\hline \multirow[t]{2}{*}{ Election_1996 x FNC t+4 x Dem_Firm } & 0.023 & 0.305 & 0.035 & 0.312 \\
\hline & $(0.15)$ & $(0.27)$ & $(0.13)$ & $(0.26)$ \\
\hline \multirow[t]{2}{*}{ Post_Election_1996 x FNC ${ }_{\mathrm{t}+4}$ X Dem_Firm } & 0.017 & 0.310 & 0.029 & 0.297 \\
\hline & $(0.32)$ & $(0.31)$ & $(0.30)$ & $(0.32)$ \\
\hline $\begin{array}{l}\text { Test: (Post_Election_1996 x FNC x } \\
\text { Dem_Firm) }- \text { (Election_1996 x FNC x } \\
\text { Dem_Firm) }>0\end{array}$ & $p=0.80$ & $p=0.95$ & $p=0.75$ & $p=0.96$ \\
\hline Observations & 12,325 & 12,325 & 11,917 & 11,917 \\
\hline R-square & 0.119 & 0.114 & 0.114 & 0.114 \\
\hline
\end{tabular}


Table 7

Real actions.

The table presents results on the relation between slanted media outlet availability and real actions around the 2000 election.

Panel A presents results on the relation between slanted media outlet availability and workforce reductions announcements around the 2000 election. The dependent variable in Columns 1 and 2 is Announced_Reductions, which is equal to the sum of the number of employees firms announced to layoff per year. The dependent variable in Columns 3 and 4 is Number_Announcements, which is equal to the sum of the number of firms' workforce-reduction and plant-closure announcements per year. In Columns 1 and 3, FNC is measured as the natural logarithm of the number of Fox News Channel subscriptions per congressional district, denoted FNC_Subscriptions. In Columns 2 and 4, FNC is an indicator equal to one if Fox News Channel was available in a particular congressional district, and zero otherwise, denoted FNC_Indicator.

Panel B presents results on the relation between slanted media outlet and workforce reductions around the 2000 election. The dependent variable in all models is Workforce Reductions, which is equal to one if a firm's reduction in employment is in the top quarter, and zero otherwise. In Column 1, FNC is measured as the natural logarithm of the number of Fox News Channel subscriptions per congressional district, denoted FNC_Subscriptions. In Column 2, FNC is an indicator equal to one if Fox News Channel was available in a particular congressional district, and zero otherwise, denoted FNC_Indicator.

Panel C presents results on the relation between slanted media outlet availability and investment reductions around the 2000 election. The dependent variable in all models is Investment_Reduction, which is equal to one if a firm's reduction in gross PP\&E is in the top quarter, and zero otherwise. In Column 1, FNC is measured as the natural logarithm of the number of Fox News Channel subscriptions per congressional district, denoted FNC Subscriptions. In Column 2, FNC is an indicator equal to one if Fox News Channel was available in a particular congressional district, and zero otherwise, denoted FNC_Indicator.

All models span the period 1998-2003. The results reported are from OLS estimations. The models include main effects, double interactions, control variables, and state as well as industry-by-year fixed effects. Main effects, double interactions, and control variables are reported in Panel A and suppressed in Panel B and C. Standard errors are clustered by state. $p$-values (two-tailed) are displayed in parentheses below the coefficient estimates. $*, * *, * * *$ represent significance at the 10, 5, and 1 percent level, respectively. Appendix A presents variable definitions.

Panel A: Announcements of workforce reductions

\begin{tabular}{|c|c|c|c|c|c|}
\hline & & FNC = FNC_Subscriptions & FNC $=$ FNC_Indicator & FNC = FNC_Subscriptions & FNC $=$ FNC_Indicator \\
\hline & & (1) & $(2)$ & (3) & $(4)$ \\
\hline Variables & Pred. & $\begin{array}{l}\text { Announced_- } \\
\text { Reductions }\end{array}$ & $\begin{array}{c}\text { Announced_- } \\
\text { Reductions }\end{array}$ & $\begin{array}{c}\text { Number_ } \\
\text { Announcements }\end{array}$ & $\begin{array}{c}\text { Number_ } \\
\text { Announcements }\end{array}$ \\
\hline \multirow[t]{2}{*}{ FNC } & & $-0.126 * *$ & -0.945 & $-0.001^{* *}$ & $-0.007 *$ \\
\hline & & $(0.02)$ & $(0.15)$ & $(0.03)$ & $(0.07)$ \\
\hline \multirow[t]{2}{*}{ Election } & & $-2.195 *$ & $-2.177 *$ & -0.007 & -0.008 \\
\hline & & $(0.06)$ & $(0.06)$ & $(0.19)$ & $(0.15)$ \\
\hline \multirow[t]{2}{*}{ Election x FNC } & & 0.055 & 0.484 & 0.000 & 0.002 \\
\hline & & $(0.30)$ & $(0.40)$ & $(0.89)$ & $(0.63)$ \\
\hline Dem_Firm & & $-1.484^{*}$ & $-2.645 * * *$ & -0.001 & -0.010 \\
\hline
\end{tabular}




\begin{tabular}{|c|c|c|c|c|c|}
\hline & & $(0.07)$ & $(0.01)$ & $(0.95)$ & $(0.46)$ \\
\hline \multirow[t]{2}{*}{ Election x Dem_Firm } & & 1.217 & 2.479 & 0.011 & 0.023 \\
\hline & & $(0.34)$ & $(0.12)$ & $(0.65)$ & $(0.38)$ \\
\hline \multirow[t]{2}{*}{ FNC x Dem_Firm } & & 0.194 & 3.833 & 0.001 & 0.024 \\
\hline & & $(0.28)$ & $(0.14)$ & $(0.65)$ & $(0.38)$ \\
\hline \multirow[t]{2}{*}{ Election x FNC x Dem_Firm } & - & $-0.322 *$ & $-4.891^{*}$ & -0.003 & $-0.051^{*}$ \\
\hline & & $(0.10)$ & $(0.06)$ & $(0.34)$ & $(0.10)$ \\
\hline \multirow[t]{2}{*}{ Post_Election } & & -5.111 & -7.065 & -0.017 & -0.019 \\
\hline & & $(0.46)$ & $(0.42)$ & $(0.40)$ & $(0.38)$ \\
\hline \multirow[t]{2}{*}{ Post_Election x FNC } & & -0.057 & -0.768 & -0.000 & -0.000 \\
\hline & & $(0.57)$ & $(0.47)$ & $(0.79)$ & $(0.95)$ \\
\hline \multirow[t]{2}{*}{ Post_Election x Dem_Firm } & & 10.973 & 4.737 & 0.067 & 0.089 \\
\hline & & $(0.24)$ & $(0.34)$ & $(0.24)$ & $(0.16)$ \\
\hline \multirow[t]{2}{*}{ Post_Election x FNC x Dem_Firm } & + & 4.162 & 55.021 & $0.014^{*}$ & 0.093 \\
\hline & & $(0.30)$ & $(0.29)$ & $(0.10)$ & $(0.44)$ \\
\hline \multirow[t]{2}{*}{ Chg_Sales } & & 0.019 & 0.012 & 0.001 & 0.001 \\
\hline & & $(0.80)$ & $(0.88)$ & $(0.19)$ & $(0.20)$ \\
\hline \multirow[t]{2}{*}{ Log_Mark_Cap } & & $1.224 * * *$ & $1.241^{* * *}$ & $0.009 * * *$ & $0.009 * * *$ \\
\hline & & $(0.01)$ & $(0.01)$ & $(0.01)$ & $(0.01)$ \\
\hline \multirow[t]{2}{*}{ Loss } & & $1.590^{* * *}$ & $1.581^{* * *}$ & $0.013^{* * *}$ & $0.013^{* * *}$ \\
\hline & & $(0.01)$ & $(0.01)$ & $(0.01)$ & $(0.01)$ \\
\hline \multirow[t]{2}{*}{ Constant } & & $-5.330 * * *$ & $-5.275^{* * *}$ & $-0.044 * * *$ & $-0.044 * * *$ \\
\hline & & $(0.01)$ & $(0.01)$ & $(0.01)$ & $(0.01)$ \\
\hline \multicolumn{6}{|l|}{ Test: (Post_Election x FNC x } \\
\hline \multicolumn{2}{|l|}{$\begin{array}{l}\text { Dem_Firm })-(\text { Election x FNC x } \\
\text { Dem_Firm })>0\end{array}$} & $p=0.07^{*}$ & $p=0.05^{*}$ & $p=0.04^{* *}$ & $p=0.08^{*}$ \\
\hline Observations & & 16,960 & 16,960 & 16,960 & 16,960 \\
\hline Pseudo R-square & & 0.055 & 0.056 & 0.069 & 0.068 \\
\hline
\end{tabular}




\begin{tabular}{lccc}
\hline Panel B: Workforce reductions & & \\
\hline & & FNC = FNC_Subscriptions & FNC = FNC_Indicator \\
\hline Variables & Pred. & Workforce_Reduction & Workforce_Reduction \\
\hline & & & \\
Election x FNC x Dem_Firm & - & $-0.106^{*}$ & $-1.208^{*}$ \\
& & $(0.09)$ & $(0.08)$ \\
Post_Election x FNC x Dem_Firm & + & -0.064 & -0.489 \\
& & $(0.26)$ & $(0.41)$ \\
Test: (Post_Election x FNC x & & & $p=0.76$ \\
Dem_Firm) - (Election x FNC x & & $p=0.61$ & \\
Dem_Firm) $>$ 0 & & \\
& & 16,960 & 16,960 \\
Observations & 0.155 & 0.155 \\
Pseudo R-square & & \\
\hline
\end{tabular}




\begin{tabular}{lccc}
\hline Panel C: Investment reductions & & \\
\hline & & FNC = FNC_Subscriptions & FNC = FNC_Indicator \\
\hline & Pred. & Investment_Reduction & Investment_Reduction \\
\hline Variables & - & & \\
\hline & & $-0.199^{*}$ & $-1.825^{*}$ \\
Election x FNC x Dem_Firm & $(0.09)$ & $(0.08)$ \\
& + & $0.100^{*}$ & 0.962 \\
Post_Election x FNC x Dem_Firm & & $(0.10)$ & $(0.19)$ \\
& & & \\
Test: (Post_Election x FNC x & & & \\
Dem_Firm) - (Election x FNC x & & & \\
Dem_Firm) $>0$ & & & \\
& & 16,960 & 16,960 \\
Observations & & 0.125 & 0.125 \\
Pseudo R-square & & \\
\hline
\end{tabular}




\section{Table 8}

Evidence from subsamples with strong economic incentives.

The table presents results on the relation between slanted media outlet availability and news suppression around the 2000 election using subsamples of firms with strong economic incentives. The dependent variable in all models is Ncskew, which is a firm's third moment of excess daily stock returns scaled by its cubed standard deviation times minus one.

In Panel A, Columns 1 and 2 use all firms identified as Democratic in Knight (2006). In Panel A, Column 1, FNC is measured as the natural logarithm of the number of Fox News Channel subscriptions per congressional district, denoted FNC_Subscriptions. In Panel A, Column 2, FNC is an indicator equal to one if Fox News Channel was available in a particular congressional district, and zero otherwise, denoted FNC_Indicator. The models include control variables (the same as in Table 4, i.e., Log_Mark_Cap, Chg_Sales, Sigma, Beta, Turnover, Lag_Turnover, Return, Lag_Return, Fortune_500,_Log_Analyst), and state, year, as well as industry fixed effects.

In Panel B, Columns 1 and 2, FNC is measured as the natural logarithm of the number of Fox News Channel subscriptions per congressional district, denoted FNC_Subscriptions. In Columns 3 and 4, FNC is an indicator equal to one if Fox News Channel was available in a particular congressional district, and zero otherwise, denoted FNC_Indicator. The models are run separately for firms who derive at least 25 percent of their revenues from government contracts (Columns 1 and 3) and all other firms (Columns 2 and 4). Panel B uses the sample of firms as defined in Table 2. The models include main effects, double interactions, control variables (the same as in Table 4, i.e., Log_Mark_Cap, Chg_Sales, Sigma, Beta, Turnover, Lag_Turnover, Return, Lag_Return, Fortune_500, Log_Analyst), and state as well as industry-by-year fixed effects.

All models span the period 1998-2003. The results reported are from OLS estimations. Standard errors are clustered by state. $p$-values (two-tailed) are displayed in parentheses below the coefficient estimates. ${ }^{*}, * *, * * *$ represent significance at the 10, 5, and 1 percent level, respectively. Appendix A presents variable definitions.

Panel A: Policy platforms

FNC $=$ FNC_Subscriptions $\quad$ FNC $=$ FNC_Indicator

(1)

\begin{tabular}{lccc} 
Variables & Pred. & Ncskew & Ncskew \\
\hline & & & -0.178 \\
FNC & & -0.017 & $(0.32)$ \\
& & $(0.31)$ & -0.470 \\
Election & -0.380 & $(0.38)$ \\
& - & $(0.48)$ & -0.446 \\
Election x FNC & & $-0.062 * *$ & $(0.24)$ \\
& & $(0.05)$ & -0.126 \\
Post_Election & + & -0.091 & $(0.42)$ \\
& & $(0.59)$ & $0.298^{*}$ \\
Post_Election x FNC & & $0.023 * *$ & $(0.09)$ \\
& & $(0.04)$ & $p=0.09 *$ \\
Test: (Post_Election x FNC) - (Election x FNC) $>0.04 * *$ & 95 \\
Observations & & & 0.569 \\
R-square & & 95 & \\
\hline
\end{tabular}




\begin{tabular}{|c|c|c|c|c|c|c|c|}
\hline \multicolumn{8}{|l|}{ Panel B: Government contractor } \\
\hline & & \multicolumn{2}{|c|}{ Government Contractor } & & \multicolumn{2}{|c|}{ Government Contractor } & \\
\hline & & Yes & No & & Yes & No & \\
\hline & & $\begin{array}{c}\text { FNC }= \\
\text { FNC_Subscriptions } \\
\end{array}$ & $\begin{array}{c}\text { FNC }= \\
\text { FNC_Subscriptions } \\
\end{array}$ & & $\begin{array}{c}\text { FNC }= \\
\text { FNC_Indicator }\end{array}$ & FNC = FNC_Indicator & \\
\hline Variables & Pred. & $\begin{array}{c}(1) \\
\text { Ncskew }\end{array}$ & $\begin{array}{c}(2) \\
\text { Ncskew }\end{array}$ & $\begin{array}{c}\text { Difference } \\
(1)-(2)\end{array}$ & $\begin{array}{c}(3) \\
\text { Ncskew }\end{array}$ & $\begin{array}{c}(4) \\
\text { Ncskew } \\
\end{array}$ & $\begin{array}{c}\text { Difference } \\
(3)-(4)\end{array}$ \\
\hline Election x FNC x Dem_Firm & - & $\begin{array}{c}-0.277^{* * *} \\
(0.01)\end{array}$ & $\begin{array}{c}-0.032^{* *} \\
(0.03)\end{array}$ & $-0.245^{* *}$ & $\begin{array}{c}-2.733^{* * *} \\
(0.01)\end{array}$ & $\begin{array}{l}-0.236 \\
(0.24)\end{array}$ & $-2.497 * * *$ \\
\hline Post_Election x FNC x Dem_Firm & + & $\begin{array}{c}0.084^{*} \\
(0.10)\end{array}$ & $\begin{array}{c}0.042^{* * * *} \\
(0.01)\end{array}$ & $0.042 * *$ & $\begin{array}{l}0.026 \\
(0.90)\end{array}$ & $\begin{array}{c}0.507^{*} \\
(0.08)\end{array}$ & $-0.481^{*}$ \\
\hline $\begin{array}{l}\text { Test: (Post_Election x FNC x } \\
\text { Dem_Firm) }- \text { (Election x FNC x } \\
\text { Dem_Firm) }>0\end{array}$ & & $p=<0.001^{* * *}$ & $p=<0.001^{* * *}$ & & $p=0.01 * * *$ & $p=<0.001^{* * *}$ & \\
\hline Observations & & 630 & 16,330 & & 630 & 16,330 & \\
\hline R-square & & 0.443 & 0.145 & & 0.439 & 0.144 & \\
\hline
\end{tabular}

